INEL-95/0477

\title{
CPP-603 Underwater Fuel Storage Facility Site Integrated Stabilization Management Plan (SISMP)
}

\section{Volume I}

R. D. Denney

Published October 1995

Idaho National Engineering Laboratory

Nuclear Operations Department

Lockheed Idaho Technologies Company

Idaho Falls, Idaho 83415

Prepared for the

U.S. Department of Energy

NMSTG : EM-60

Under DOE Idaho Operations Office

Contract DE-AC07-94ID13223

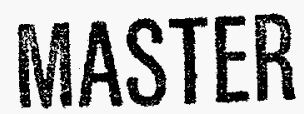




\section{DISCLAIMER}

Portions of this document may be illegible in electronic image products. Images are produced from the best available original document. 


\section{SUMMARY}

The CPP-603 Underwater Fuel Storage Facility (UFSF) Site Integrated Stabilization Management Plan (SISMP) has been constructed to describe the activities required for the relocation of spent nuclear fuel (SNF) from the CPP-603 facility. These activities are the only Idaho National Engineering Laboratory (INEL) actions identified in the Implementation Plan developed to meet the requirements of the Defense Nuclear Facilities Safety Board (DNFSB) Recommendation 94-1 to the Secretary of Energy regarding an improved schedule for remediation in the Defense Nuclear Facilities Complex.

As described in the DNFSB Recommendation 94-1 Implementation Plan, issued February 28, 1995, an INEL Spent I Juclear Fuel Management Plan is currently under development to direct the placement of SNF currently in existing INEL facilities into interim storage, and to address the coordination of intrasite SNF movements with new receipts and intersite transfers that were identified in the DOE SNF Programmatic and INEL Environmental Restoration and Waste Management Environmental Impact Statement Record of Decision. This SISMP will be a subset of the INEL Spent Nuclear Fuel Management Plan and the activities described are being coordinated with other INEL SNF management activities. The CPP- 603 relocation activities have been assigned a high priority so that established milestones will be meet, but there will be some cases where other activities will take precedence in utilization of available resources.

The Draft INEL Site Integrated Stabilization Management Plan (SISMP), INEL-94/0279, Draft Rev. 2, dated March 10,1995, is being superseded by the INEL Spent Nuclear Fuel Management Plan and this CPP-603 specific SISMP.

\section{DISCLAIMER}

This report was prepared as an account of work sponsored by an agency of the United States Government. Neither the United States Government nor any agency thereof, nor any of their employees, makes any warranty, express or implied, or assumes any legal liability or responsibility for the accuracy, completeness, or usefulness of any information, apparatus, product, or process disclosed, or represents that its use would not infringe privately owned rights. Reference herein to any specifis: commercial product, process, or service by trade name, trademark, manufacturer, or otherwise does not necessarily constitute or imply its endorsement, recommendation, or favoring by the United States Government or any agency thereof. The views and opinions of authors expressed herein do not necessarily state or reflect those of the United States Government: or any agency thereof. 


\section{CONTENTS}

SUMMARY iii

ACRONYMS vi

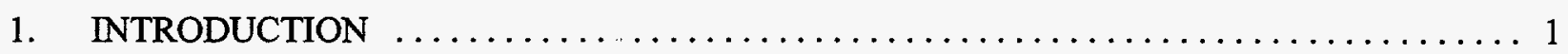

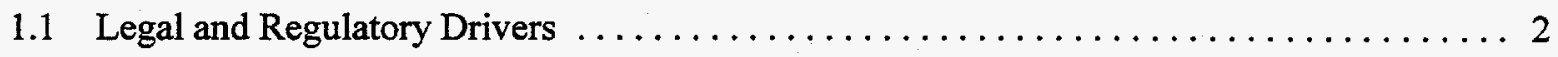

1.2 Fuel Management Considerations $\ldots \ldots \ldots \ldots \ldots \ldots \ldots \ldots \ldots \ldots \ldots \ldots \ldots \ldots \ldots \ldots \ldots \ldots \ldots \ldots$

1.3 Systems Engineering Validation $\ldots \ldots \ldots \ldots \ldots \ldots \ldots \ldots \ldots \ldots \ldots \ldots \ldots \ldots \ldots \ldots \ldots \ldots$

1.4 General Organizational Responsibilities and Interfaces $\ldots \ldots \ldots \ldots \ldots \ldots \ldots \ldots$

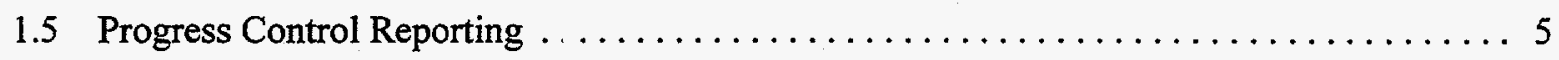

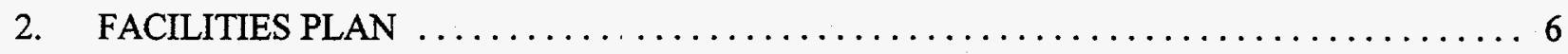

2.1 CPP-603 Underwater Fuel Storage Facility $\ldots \ldots \ldots \ldots \ldots \ldots \ldots \ldots \ldots \ldots$

2.2 CPP-666 Fuel Storage Area $\ldots \ldots \ldots \ldots \ldots \ldots \ldots \ldots \ldots \ldots \ldots \ldots \ldots \ldots$

2.3 CPP-603 Irradiated Fuel Storage Facility $\ldots \ldots \ldots \ldots \ldots \ldots \ldots \ldots \ldots \ldots \ldots$

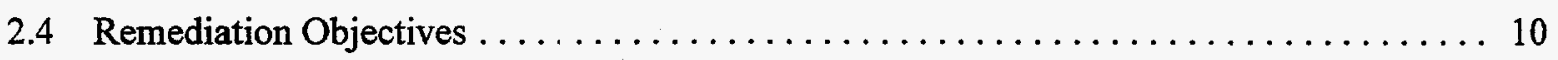

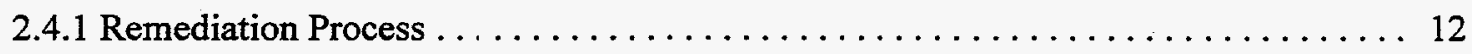

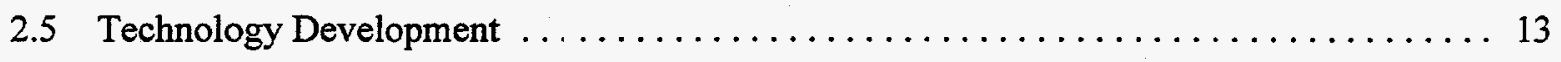

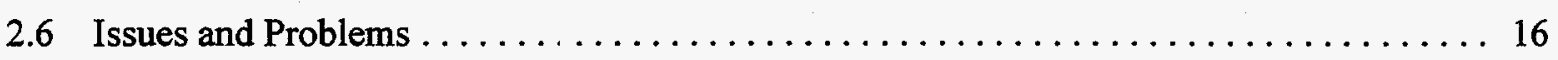

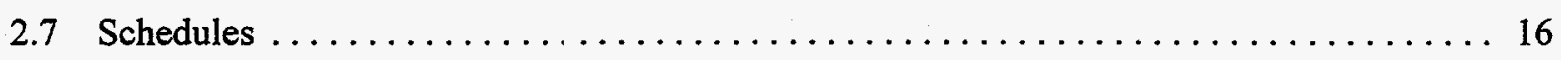

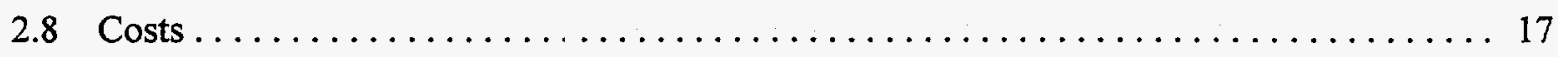

FIGURES

1-1. Nuclear Operations organizational chart $\ldots \ldots \ldots \ldots \ldots \ldots \ldots \ldots \ldots \ldots \ldots \ldots \ldots$

2-1. CPP-603 underwater fuel storage facility $\ldots \ldots \ldots \ldots \ldots \ldots \ldots \ldots \ldots \ldots \ldots \ldots \ldots$

2-2. CPP-666 fuel storage area $\ldots \ldots \ldots \ldots \ldots \ldots \ldots \ldots \ldots \ldots \ldots \ldots \ldots \ldots \ldots \ldots$ 
2-3. CPP-603 irradiated fuel storage facility

2-4. CPP 603 fuel movements (by phases) diagram .

\section{TABLES}

1-1. Implementation plan program managers 


\section{ACRONYMS}

\begin{tabular}{|c|c|}
\hline$A N L-W$ & Argonne National Laboratory-West \\
\hline ANP & Aircraft Nuclear Propulsion \\
\hline APPR & Army Package Power Reactor \\
\hline ARMF & Advanced Reactivity Measurement Facility \\
\hline ATR & Advanced Test Reactor \\
\hline BMI & Battelle Memorial Institute \\
\hline $\mathrm{CCB}$ & Change Control Board \\
\hline CFR & Code of Federal Regulations \\
\hline CFRMF & Coupled Fast Reactivity Measurement Facility \\
\hline DNFSB & Defense Nuclear Facility Safety Board \\
\hline DOE & Department of Energy \\
\hline$-\mathrm{EM}$ & Office of Environmental Restoration and Waste Management \\
\hline$-\mathrm{HQ}$ & Headquarters \\
\hline$-\mathrm{ID}$ & Idaho Operations Office: \\
\hline EBR & Experimental Breeder Reactor \\
\hline $\mathrm{ECF}$ & Expended Core Facility \\
\hline EIS & Environmental Impact Statement \\
\hline FDP & Fluorinel Dissolution Process \\
\hline FHC & Fuel Handling Cave \\
\hline FHU & Fuel Handling Unit \\
\hline FSA & Fuel Storage Area \\
\hline FY & Fiscal Year \\
\hline GETR & General Electric Test Rњactor \\
\hline HEPA & High-Efficiency Particulate Air (Filter) \\
\hline HVAC & Heating, Ventilating, and Air Conditioning \\
\hline ICPP & Idaho Chemical Processing Plant \\
\hline IFSF & Irradiated Fuel Storage Facility \\
\hline NEL & Idaho National Engineering Laboratory \\
\hline KAPL & Knolls Atomic Power Laboratory \\
\hline LITCO & Lockheed Idaho Technologies Company \\
\hline MTR & Materials Test Reactor \\
\hline MURR & Missouri University Res:earch Reactor \\
\hline
\end{tabular}




$\begin{array}{ll}\text { NMSTG } & \begin{array}{l}\text { Nuclear Materials Stabilization Task Group } \\ \text { NRC }\end{array} \\ \text { ORR } & \text { Opuclear Regulatory Commission } \\ \text { PTS } & \text { Progress Tracking System } \\ \text { RCRA } & \text { Resource Conservation and Recovery Act } \\ \text { ROD } & \text { Record of Decision } \\ \text { QA } & \text { Quality Assurance } \\ \text { SAR } & \text { Safety Analysis Report } \\ \text { SIR } & \text { Submarine Intermediate Reactor } \\ \text { SISMP } & \text { Site Integrated Stabilization Management Plan } \\ \text { SM-1A } & \text { Stationary Medium Power Plant } \\ \text { SNAP } & \text { System for Nuclear Auxiliary Power } \\ \text { SNF } & \text { Spent Nuclear Fuel } \\ \text { SRS } & \text { Savannah River Site } \\ \text { TORY } & \text { Experimental Propulsion Test Reactor } \\ \text { TRIGA } & \text { Training, Research and Irradiation Reactor-General Atomics } \\ \text { UFSF } & \text { Underwater Fuel Storage Facility } \\ \text { VBWR } & \text { Vallecitos Boiling Water Reactor } \\ \text { WAPD } & \text { Westinghouse Atomic Power Development } \\ & \\ \text { Ond } & \end{array}$




\section{CPP-603 Underwater Fuel Storage Facility Site Integrated Stabilization Management Plan (SISMP)}

\section{INTRODUCTION}

On May 26, 1994, the Defense Nuc lear Facilities Safety Board (DNFSB) unanimously approved Recommendation 94-1 to the Secretary of Energy, regarding an "Improved Schedule for Remediation in the Defense Nuclear Facilities Complex." The DNFSB recommendations are aimed at imminent hazards which could arise if material management problems are not corrected. The DNFSB recommended that the Department of Energy (DOE):

- Formulate an integrated program plan to convert the affected materials to forms or conditions suitable for safe interim storagse

- Establish a research program to fill any gaps in the information base needed for choosing among the alternate processes to be used in safe conversion of various types of fissile materials to optimal forms for safe interim storage and long-term dispositioning

- Maintain those facilities that may be needed for the future handling and treatment of nuclear materials in a usable state

In a response to DNFSB Recommeridation 94-1, dated August 31, 1994, Secretary of Energy Hazel R. O'Leary committed the DOE to develop an Integrated Program Plan which "includes a systems engineering approach to maximize the integration of facilities and capabilities while minimizing worker exposures and additional waste; research programs required to fill any gaps in the technological information base; identification of those facilities that may be needed for future handling and treatment of these materials; [and] ensuring operational readiness in accordance with DOE Order 5480.31 [Startup and Restart of Nuclear Facilities]."

The DNFSB Recommendation 94-1 Implementation Plan, issued February 28, 1995, was issued by $\mathrm{DOE}$ as its integrated program plan and provides the schedules and major milestones for achieving the recommended objectives. This Implemeritation Plan requires each affected site to prepare a Site Integrated Stabilization Management Plan (SISMP) that documents the activities at each site to prepare a response to the objectives and requiremerits of the Implementation Plan. This document meets those requirements.

The general overview of the CPP-6(13 facility involves the discharge of Spent Nuclear Fuel (SNF) to comply with a U. S. District Court Order issued in September 1993. Removing SNF from CPP-603 will correct percived deficiences, which inclucle corrosion-damaged SNF encapsulation and hangers, facility structure, resistance to seismic events, and water-leak detection. The overall objective is to provide safe interim storage of these SNF for preparings the facility for deactivation. 


\subsection{Legal and Regulatory Drivers}

In response to environmental questions raised by the State of Idaho concerning the shipment and subsequent storage of Fort St. Vrain spent nuclear fuel (SNF) at the Idaho Chemical Processing Plant (ICPP), Senior United States District Judge H. L. Ryan issued an Opinion and Order, dated June 28, 1993, requiring DOE to prepare an Environmental Impact Statement (EIS), evaluate alternatives to Idaho National Engineering Laboratory (NEL) SNF storage, and cease further input of SNF at the INEL until the comprehensive EIS is completed, reviewed, and any challenges to the statement are resolved. Subsequently, Hazel R. O'Leary, Secretary of Energy; John H. Dalton, Secretary of the Navy; and Cecil B. Andrus, Governor of the State of Idaho, entered into an agreement on August 9, 1993, proposing modifications to the U.S. District Court's Opinion and Order of June 28, 1993. On December 22, 1993, Judge H. L. Ryan issued an order ratifying the proposed modifications. Removal of the CPP-603 Underwater Fuel Storage Facility (UFSF) from service on a schedule mandated by the following milestones is a requirement of this court order.

- Remove 189 storage units from the North and Middle Basins by September 1994 (completed July 26, 1994)

- Commence the removal and transfer of South Basin fuel units on or before by June 1,1995 (completed May 12, 1995)

- Remove 189 additional storage units from the North and Middle Basins by December 31, 1995 (completed September 11, 1995)

- Remove remaining 244 storage units from the North and Middle Basins by December 31, 1996

- Transfer all units from the South Basin by December 31, 2000

DOE may also "procure spent fuel storage racks suitable for use in reracking the Fuel Storage Area of Building $666 \ldots$ provided that the racks will not be brought on-site or installed at that building, if at all, until the EIS process is completed ..." All other program drivers and milestones have been established internally to expedite compliance with the Court Order and to facilitate consolidation of SNF across the INEL.

\subsection{Fuel Management Considerations}

Since reprocessing within the United States was limited, major changes in the priorities and mission of the INEL have occurred. INEL SNF storage systems were being operated using materials and storage arrangements designed to support SNF reprocessing, that is, short periods of temporary underwater storage. INEL interim planning for these facilities is being adjusted to the revised mission of safe, cost effective, interim storage and preparation of SNF for shipment to the national repository in an integrated program that also is consistant with overall INEL waste stream strategic planning. In accordance with the DOE-Owned Spent Nuclear Fuel Strategic Plan (December 1994), the INEL is committed to prompt resolution of identified SNF facility safety vulnerabilities via SNF removal from aging underwater storage pools and consolidation into qualified existing storage facilities or into new modular dry storage that also 
supports (if possible) the mission to prepare the SNF for shipment to a repository. These vulnerabilities have been identified in the DOE Plan of Action to Resolve Spent Nuclear Fuel Vulnerabilities (Phase III Report, dated October 1994).

\subsection{Systems Engineering Validation}

Systems engineering is a top down analysis of requirements, alternatives, and potential actions to analytically determine the best approach to performing difficult or complicated tasks. Systems engineering is being used at the DOE National SNF Program level to identify the DOE program requirements and functions and is now being promulgated into the INEL SNF program to identify the best mission alternatives for movement to qualified existing or new facilities. Although this SISMP will be completed prior to the full completion of a systems engineering analysis, systems analysis will be used in future months to validate or potentially adjust the SNF management approach being presented here.

\subsection{General Organizational Responsibilities and Interfaces}

Multiple organizations are involved in supporting the activities identified in this SISMP. Within the DOE-Idaho Operations Office (DOE-ID) the Spent Fuel Program manager is responsible for the overall management, administration, and performance of the INEL Spent Nuclear Fuel Program to ensure that long range planning, budgeting, and integration is accomplished to support the assigned SNF mission at the INEL. The DOE Facility Manager for the ICPP is responsible for implementation of the SNF program at the required levels of quality, safety, and environmental compliance, and within established technical, cost, and schedule baselines.

Lockheed Idaho Technologies Company (LITCO) is the operating contractor for most INEL programs and facilities, and has overall responsibility for management and operations. Within LITCO, the Nuclear Operations branch is responsible for all nuclear operations programs. Under this branch, the National Spent Fuel and Related Programs directorate includes the INEL Spent Nuclear Fuel Program Department which is responsible for the INEL SNF long range programmitic planning and integration activities, and for providing new facilities which have been identified to be necessary for the SNF mission. Also under the Nuclear Operations branch is the Nuclear Fuel Operations directorate which includes the Fuel Operations Department and associated supporting departments. The Fuel Operations Department is responsible for operation and maintenance of SNF facilities and implementation of the INEL SNF program. An organizational chart of the Nuclear Operations branch as it involves SNF is provided in Figure 1-1.

Specifically, for the CPP-603 SNF removal activities identified in this SISMP, the long range planning has been established by the court ordered milestones, and the overall detailed planning and implementation is the responsibility of the Fuel Operations Department. Support is being provided by: (a) INEL Spent Nuclear Fuel Program, ( $b_{1}$ ) Engineering and Project Management (c) Maintenance and Facility Operations, (d) Plant Support, (e) Training and Administrative Support, (f) Environmental Safety 


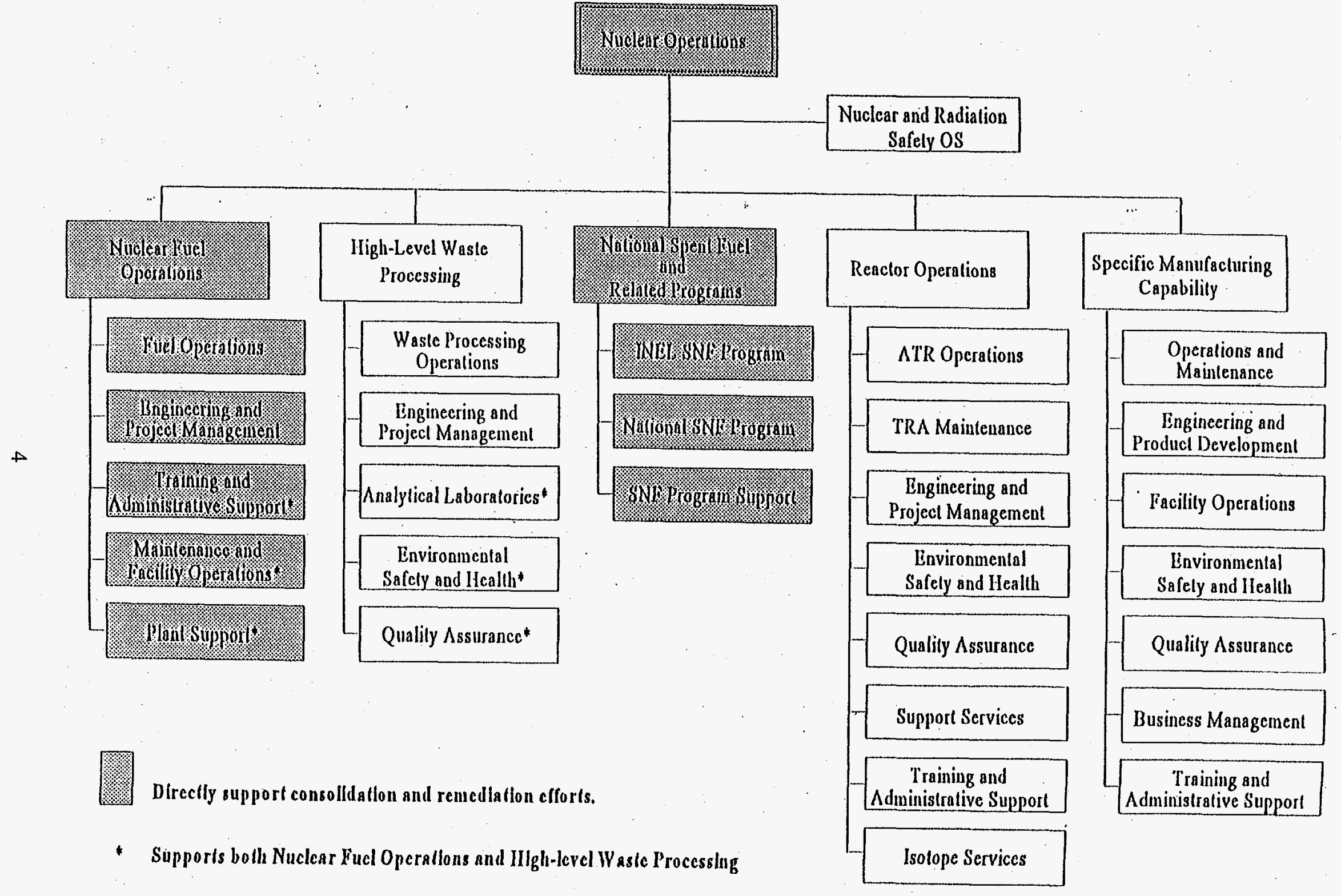

Figure 1-1. Nuclear Operations organizational chart. 
and Health, and (g) Quality, and other associated support organizations as established by the activity schedules.

Interface with the DOE Nuclear Materials Stabilization Task Group (NMSTG), which is responsible for integration of the DNFSB Recommendation 94-1 activities across all DOE sites is being provided by the INEL Spent Nuclear Fuel Program department via development of this INEL SISMP and through monthly status reports. Personnel assigned to specifically support the NMSTG Integration Working Group and Research Committee are also under the direction of the INEL Spent Nuclear Fuel Program. Table 1-1 lists the organizational title and telephone number for the CPP-603 94-1 Implementation Plan Prógram managers.

\subsection{Progress Control Reporting}

INEL SNF programs are mostly funded through the DOE Office of Environmental Restoration and Waste Management (DOE-EM), EM-30, and more specifically through the Office of Western Waste Management Operations, EM-35. The Office of Waste Management utilizes Activity Data Sheets (ADS) to define major work activities for its programs. The technical work scope and budgeted costs are developed and approved annually through a 7-year budget call at the EM-30 level, and then more detailed plans are approved by DOE-ID just prior to initiating each fiscal year. Progress and reporting milestones are negotiated with DOE-EM and DOE-II) and are tracked in the DOE-EM Progress Tracking System (PTS). ADS level changes are approved by DOE-ID.

For the activities identified in this SISMP, progress on the major milestones and changes to the detailed schedules are provided monthly to the NMSTG by the INEL Spent Nuclear Fuel Program.

- Monthly status reports on the corrective actions identified in the DOE Plan of Action to Resolve Spent Nuclear Fuel Vulnerabilities, which includes the same CPP-603 SNF removal schedules as this SISMP, are provided to DOE-ID, DOE Headquarters (-HQ) EM-35 and EM-37 (the Office of Spent Fuel Management) by the Spent Nuclear Fuel Program.

Table 1-1. Implementation plan prograrn managers.

\begin{tabular}{llll}
\hline \multicolumn{1}{c}{ Organization or activity title } & \multicolumn{1}{c}{ Personnel } & Company & Phone \\
\hline Nuclear Operations Vice President & H. B. Barron & LITCO & $208-526-4437$ \\
Nuclear Fuel Operations/Directorate & T. A. Mathews & LITCO & $208-526-8710$ \\
Stored SNF Department & J. E. Kaylor & LITCO & $208-526-3483$ \\
INEL Spent Nuclear Fuel Program & A. P. Hoskins & LITCO & $208-526-4620$ \\
Operations Manager ICPP & W. D. Jensen & DOE-ID & $208-526-7500$ \\
Operations Technology Support & C. R. Enos & DOE-ID & $208-526-0108$ \\
INEL SNF Program & R. C. Stump & DOE-ID & $208-526-1448$ \\
INEL 94-1 Implementation Plan Manager & W. L. Scott & DOE-ID & $208-526-8184$ \\
\hline
\end{tabular}




\section{FACILITIES PLAN}

The purpose of this section is to discuss what facilities and facility capabilities will be used to undertake the stabilization activities. The facilities involved in the CPP-603 SISMP include the CPP-603 Undewater Fuel Storage Facility (UFSF), the CPP-666 Fuel Storage Area (FSA), and the Irradiated Fuel Storage Facility (IFSF) which is part of the CPP-603 facility. A brief description of the facilities is provided with associated work activities necessary for continued operations and detailed work plans and processes for completing the SISMP objectives. In addition, a section is included to discuss potential issues and problems.

The DNFSB's 1994 recommendation that remediation be completed on the CPP-603 basins "within three to eight years" was noted. However, a tri-party agreement, manifested in a Court Order, was reached between DOE, Navy, and the State of Idaho in August 1993, wherein all SNF would be removed from the wet storage basins by December 31,2000, based on the best approach possible, under the technical circumstances. CPP-603 activities are being undertaken on a schedule to meet the court ordermandated milestones or to accelerate the schedule if possible. The milestones have been identified by DOE-HQ in the Implementation Plan with mission numbers and are provided as follows:

- Completed before \# established-Establishment of the Facility Safety Authorization Basis- (completed, including rerigging of storage equipment, System for Nuclear Auxiliary Power [SNAP] fuel canning, video inspection of all spent fuel and storage equipment, and seismic evaluation)

- $\quad$ Completed before \# established-Movement of first 189 units from the North and Middle Basins to CPP- 666 by September 30, 1994 (completed July 26, 1994)

- IP-3.6-045-Movement of South Basin Fuels-Begin by June 1, 1995 (completed May 12, 1995)

- IP-3.6-043-Movement of second 189 units from the North and Middle Basins to CPP-666 by December 31, 1995 (completed September 11, 1995)

- IP-3.6-044-Removal of all SNF from North and Middle Basins by December 31, 1996

- IP-3.6-046-Removal of all SNF not requiring overpacking by December 31, 1998

- $\quad$ IP-3.6-047-Dry Storage Overpacking Station construction and startup by December 31, 1998

- IP-3.6-005-SNF removal from the CPP-603 South Basin by December 31, 2000

\subsection{CPP-603 Underwater Fuel Storage Facility}

The CPP-603 UFSF at the ICPP comprises of three interconnected underwater fuel storage basins (North, South, and Middle), and associated fuel transfer stations, as shown in Figure 2-1. Various types of nuclear fuels are handled and stored in the underwater basins at the facility. The facility is supported by cranes, two cask loading and unloading areas, and truck loading and unloading bays adjacent to the 


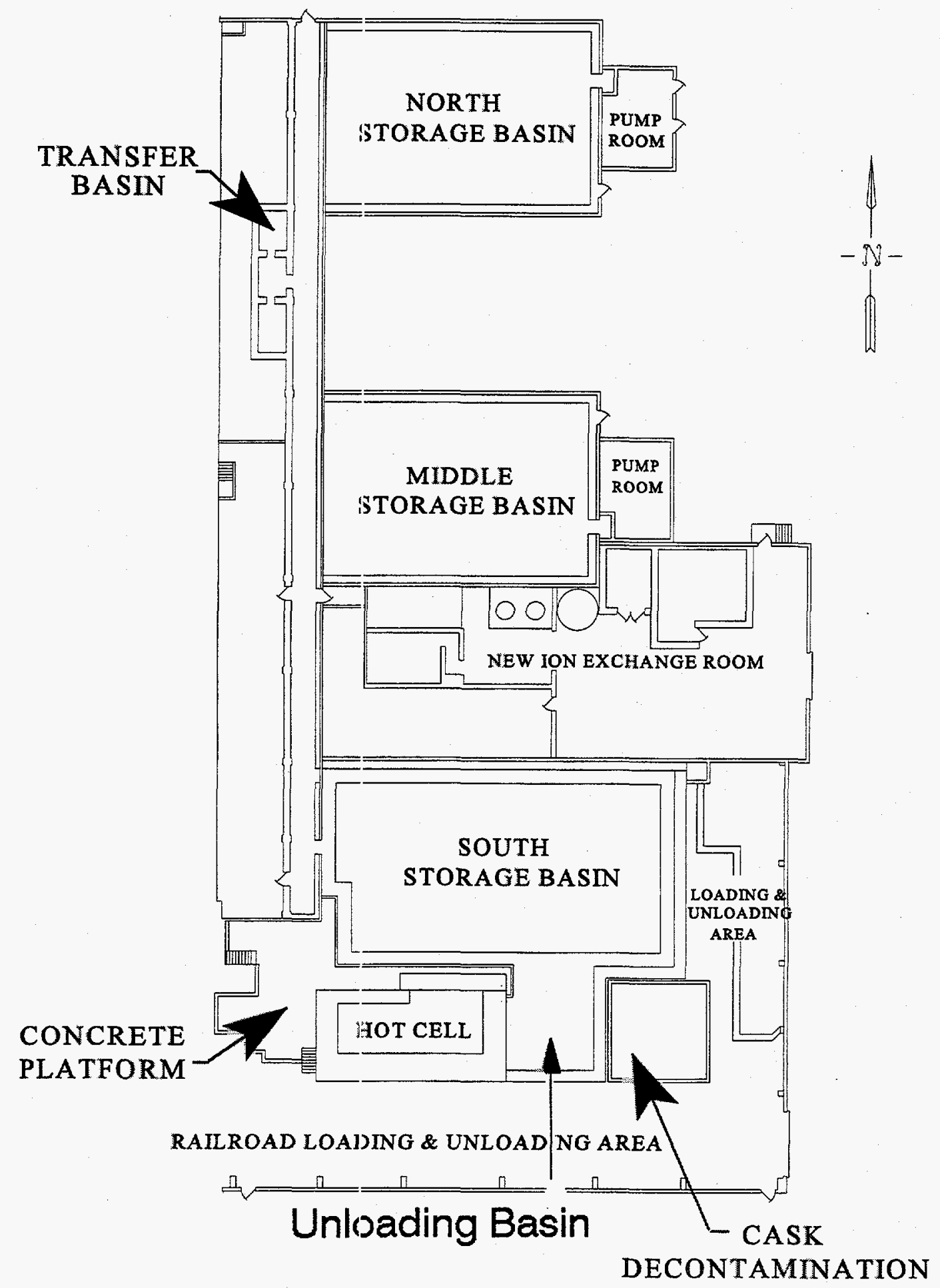

Figure 2-1. CPP-603 underwater fuel storage facility. 
basins. The IFSF, see Section 2.3, is an extension of this facility. A cask decontamination pad is located near the South basin. In the past, SNF was received and swopped out through two unloading stations containing cask loading and unloading pits. SNF is handled in units known as fuel handling units (FHU's) or "storage units." FHUs may consist of one or more individual pieces of fuel packaged into a single handling unit. FHUs stored in the CPP-603 Underwater Storage Facility are either stored in underwater racks in the South Basin or supported from yokes connected to a monorail system in the North and Middle Basins. Fuel is transferred out of the basins using cask transfer pits. One pit is located near the north basin to support the north and middle basins and another is located near the south basin to support the south basin. Shielded casks or chargers containing the fuel to be transferred to the basin (or empty to transfer fuel out of the basin) are lowered into the basin using overhead cranes. The fuel is then loaded into the cask or charger and raised above the water surface and drained over the pool for a brief period prior to transfer to the wipe down area. The water is maintained by a continuously circulated cleanup system that includes sandfilters, ion exchange columns, and an ultraviolet light. The basins consist of unlined concrete. The overhead structure consists of a stainless steel framework covered with transit siding. There is no ventilation control system.

\subsection{CPP-666 Fuel Storage Area}

The CPP-666 Fuel Storage Area is an underwater fuel storage facility comprising six storage pools, two unloading pools and two isolation pools, a fuel transfer canal, an enclosed fuel cutting pool, and a direct fuel transfer route into the Fluorinel Dissolution Process (FDP) Cell, as shown in Figure 2-2). The facility is designed to meet all current design requirements for non-reactor nuclear facilities. The pools are stainless steel lined, with a leak detection system. The facility has an extensive water chemistry control system and a heating, ventilation, and air conditioning (HVAC) confinement system. Fuel can be received at the facility by truck. Cask transport into one of two fuel unloading pools is performed using a 130-ton bridge crane (unloading pools are $19 \times 19 \times 36 \mathrm{ft}$ deep and $20 \times 24 \times 44 \mathrm{ft} \mathrm{deep).} \mathrm{The} \mathrm{six} \mathrm{main}$ storage pools are each $31 \times 46 \mathrm{ft}$ with depths of either 31 or $41 \mathrm{ft}$, serviced by two 10-ton bridge cranes. The $10 \times 221 \times 31 \mathrm{ft}$ deep transfer canal allows underwater transfer of materials between storage locations. In addition, there are two isolation pools $(8 \times 19 \mathrm{ft}$ and $8 \times 24 \mathrm{ft}$ ) and a fuel cutting pool (43 $\times$ $16 \mathrm{ft}$ ) which has been drained of water and is currently not available. Storage of fuel at the facility started in 1984. All fuels in storage are in free standing racks which provide criticality-safe storage via geometric spacing. The facility currently receives fuel from Naval, Advanced Test Reactor (ATR) and CPP-603 sources.

CPP-666 operations currently involves the receipt of approximately 272 SNF shipments per year (60 Naval, 12 ATR, 200 CPP-603) in addition to maintenance of pool storage conditions, fuel testing, and other functions. Continued operation requires provisions for a number of support functions to ensure that the facilities are operated safely and effectively.

The CPP-666 facility is the INEL receiving facility for most SNF which has significant decay heat. It also houses SNF that may react with a dry storage environment. Careful operations coordination at CPP-666 will be required to manage CPP-603 inputs and other potential SNF receipts without impacting the receipt of Naval and ATR fuel for cooling. 


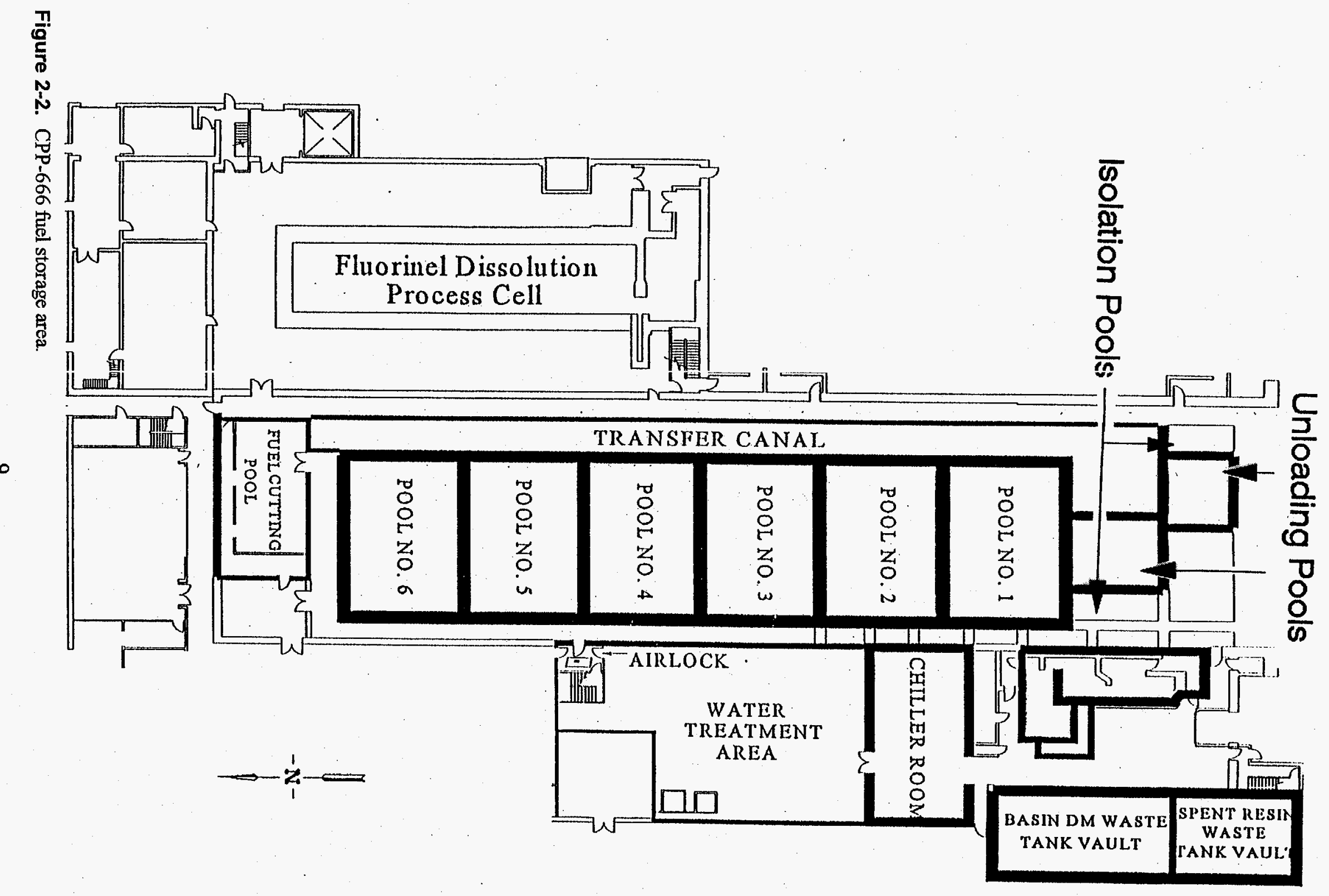




\subsection{CPP-603 Irradiated Fuel Storage Facility}

The IFSF, see Figure 2-3, was built in 1973 as an extension to CPP-603. The facility was designed to provide handling capability and dry vault storage capacity for graphite matrix fuels, specifically the Ft. St. Vrain and Peach Bottom (PB) Core II fuel. The Fuel Handling Cave (FHC) is used to transfer SNF into the IFSF. The handling cave contains a shielded transfer car to receive the shipping casks loaded with fuel elements or canisters, a shuttle bin to place SNF in storage, 15 ports or cavewells to facilitate fuel handling and to provide for temporary storage, and fuel handling equipment (i.e., a crane, $\mathrm{PaR}$ manipulator (remote equipment), and master slave manipulator).

The facility was designed to withstand a safe shutdown earthquake as well as the applicable design basis tornado. Analyses are being completed to resolve concerns about postulated structural inadequacies in the storage racks and the concrete roof structure. Structural seismic analysis is required to verify the acceptability of the facility or define upgrade requirements for continued use of the CPP-603 IFSF within the current DOE regulatory framework. There are 636 storage containers in the IFSF fuel storage area; of these, over 300 are empty and available for additional fuel receipts. The containers are 18 inches in diameter and eleven feet tall. The IFSF has a forced air cooling system that has High-Efficiency Particulate Air (HEPA) filtration. The FHC has adequate space for an SNF canning station which is currently being designed for installation in FY-96.

\subsection{Remediation Objectives}

The overall remediation objective for CPP-603 is specifically outlined in the June 28, 1995 Opinion and order issued by Senior United States District Judge H. L. Ryan. The CPP-603 SNF inventory will be moved to the CPP-666 facility unless alternate agreements, currently in progress, are made with the State of Idaho.

The DNFSB's 1994 recommendation that remediation be completed on the CPP-603 basins "within three to eight years" was noted. However, a tri-party agreement, manifested in a Court Order, was reached between DOE, Navy, and the State of Idaho in August 1993, wherein all SNF would be removed from the wet storage basins by December 31,2000, based on the best approach possible, under the technical circumstances. CPP-603 activities are being undertaken on a schedule to meet the court ordermandated milestones or to accelerate the schedule if possible. The milestones have been identified by DOE-HQ in the Implementation Plan with mission numbers and are provided as follows:

- Completed before \# established-Establishment of the Facility Safety Authorization Basis-(completed including rerigging, of storage equipment, System for Nuclear Auxiliary Power [SNAP] fuel canning, video inspection of all spent fuel and storage equipment, and seismic evaluation)

- $\quad$ Completed before \# established-Movement of first 189 units from the North and Middle Basins to CPP-666 by September 30, 1994 (completed July 26, 1994)

- IP-3.6-045-Movement of South Basin Fuels-Begin by June 1, 1995 (completed May 12, 1995) 


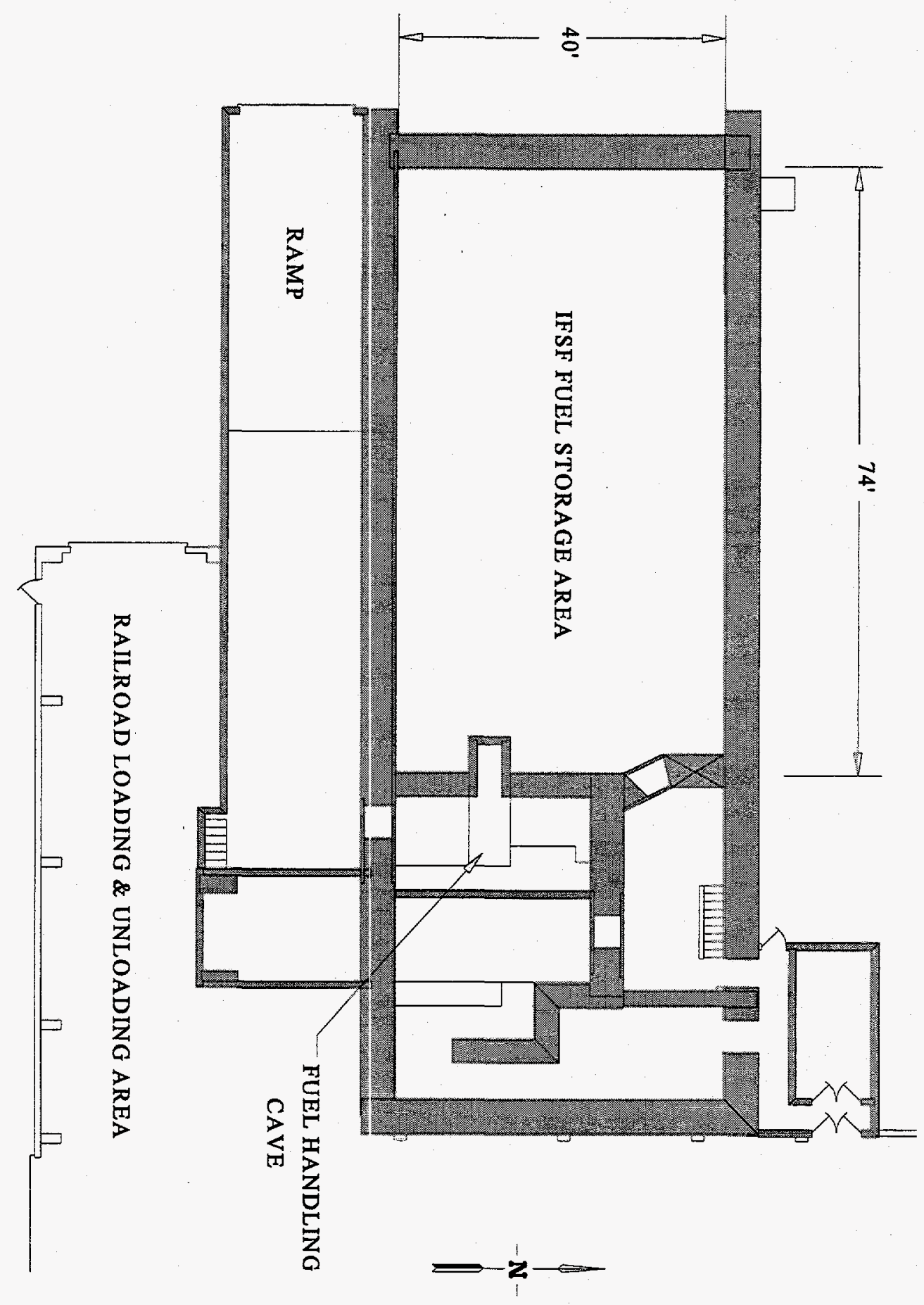

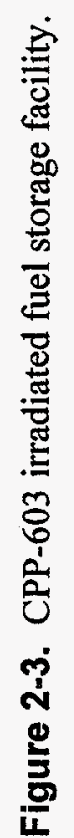


- IP-3.6-043-Movement of second 189 units from the North and Middle Basins to CPP-666 by December 31, 1995 (completed September 11, 1995)

- IP-3.6-044-Removal of all SNF from North and Middle Basins by December 31, 1996

- IP-3.6-046-Removal of all SNF not requiring overpacking by December 31, 1998

- IP-3.6-047-Dry Storage Overpacking Station construction and startup by December 31, 1998

- IP-3.6-005-SNF removal from the CPP-603 South Basin by December 31, 2000.

The intact SNF (Naval and stainless steel) will be transferred to the CPP-666 facility utilizing available transport casks. Each fuel type will require the design and procurement of specific storage buckets and tools to accomplish the movements, and in turn, require additional support documentation including appropriate safety analysis, technical standards, operating procedures, training, and readiness assessments prior to transfer to CPP-666. In addition, certain uranium alloy and aluminum plate type fuels and a few exotic fuels will require drying and storage in a dry storage facility. Moving these fuels into dry storage will inhibit further corrosion of the existing fuel containers or cladding. This will be accomplished by placing the fuel or fuel cans in new canisters that will contain fuel, fuel fragments; and fission, activation, and corrosion products. After drying the canisters will be moved to dry storage, based upon approval from the State of Idaho.

\subsubsection{Remediation Process}

An in depth independent readiness assessment was performed at CPP-603 to demonstrate operational readiness to continue (after the initial 199 transfers) transfer of SNF from CPP-603 North and Middle Basins to CPP-666. The scope included a graded approach to the fuel handling processes, procedures, techniques, training, tools, safety assessments, and other operations needed to safely transfer and store SNF from CPP-603 to CPP-666. Also, another independent readiness assessment was conducted for CPP-603 South Basin fuels to initiate transfers. When the fuel transfer activities are completed for one fuel type and prior to starting transfers of another fuel type, a limited scope readiness assessment will be conducted. Following the completion of the first 189 SNF transfers, the remaining placement of CPP-603 SNF into acceptable containers and removal from CPP-603 has been divided into eight phases depending on fuel type, configuration and storage approval status. Each relocation phase will require engineering baseline development, which includes design criteria, design engineering, possible mock-ups, procurement, fabrication and testing, tool validation, operator training, procedures, criticality safety evaluations, safety assessments, technical standard revisions and readiness assessments. Fuel movements will begin upon completion of these engineering development activities. Figure 2-4 provides a simplified flow diagram of those planned 8 phases. There is no specific assignment of the phases to the major milestones established in the federal court order. Instead, the preparation activities for the various phases are being worked in a manner to allow SNF from different phases to be ready to transfer so milestones will be met, even if difficulties with a fuel type develop. Revisions to the plans concerning which SNF will be moved to meet the milestones will be made as part of the normal SNF management operations. 
In conclusion, the overview remediation objective of the CPP-603 facility involves the discharge of Spent Nuclear Fuel (SNF) to comply with a U. S. District Court Order issued in September 1993.

Removing SNF from CPP-603 will correst percived deficiences, which include corrosion-damaged SNF encapsulation and hangers, facility structure, resistance to seismic events, and water-leak detection. The overall objective is to provide safe interin storage of these SNF for preparing the facility for deactivation.

\subsection{Technology Development}

No technology deveolpement issues have been identified to date, with the exception of scoping studies to identify tools and equipment required for fuel repackaging, transportation, and storage in CPP666. This section is provided to address technology development activities that although are not directly related to technology developement, they are required from a support standpoint utilizing existing technology for the fuel movements. These support activities are required because of the degraded condition of the SNF does not allow in all cases standard methods for removing the SNF. These methods for transferring SNF will require additional support techniques to accomplish the SNF movements.

Fuels located at the CPP-603 facility were not prepared for long-term storage. Due to the condition of some SNF storage equipment (cans, yckes, racks) and aluminum clad fuel stored in CPP-603, the main issues and problems are associated with the lifting, handling, and packaging of the SNF within the CPP603 facility. Corrosion is the primary constraint complicating the movements of the SNF from CPP-603. Corrosion may deteriorate canned fuels resulting in the possibility of losing containment, increasing challenges related to retrievability if the can is damaged, and accelerating corrosion if water has leaked into the cans.

Reactive SNF management is a long-term technical problem for the DOE complex. Reactive fuels are defined as metallic fuel, fuel with organic (hydrogen based) contamination, or fuel with inorganic chemical compounds which could react with gas atmospheres in a dry storage environment and result in an unsafe condition. Interim movement of reactive or potentially reactive SNF from CPP-603 wet storage to a dry environment is requiring development of stabilization processes for the safe dry storage of the fuel. Development will be focused on:

- Determining the packaging and storage requirements for SNF with potentially failed cladding

- $\quad$ Providing complete drying of the SNF without unacceptable chemical reactions

- $\quad$ Providing stabilization processing treatments to eliminate the SNF reactivity problem

- $\quad$ Removing organic materials from SNF to eliminate pressure generating radiolysis reactions

- Inspection of cans for water irtrusion.

Safe dry storage systems and config,urations for reactive SNF will be required before wet SNF storage can be eliminated. Inspection of fuel and fuel canisters is required to characterize the fuel materials and ensure that the planned prosessing will stabilize the fuel for dry storage. Development of underwater capabilities for ultrasound and eddy-current nondestructive testing are required. 


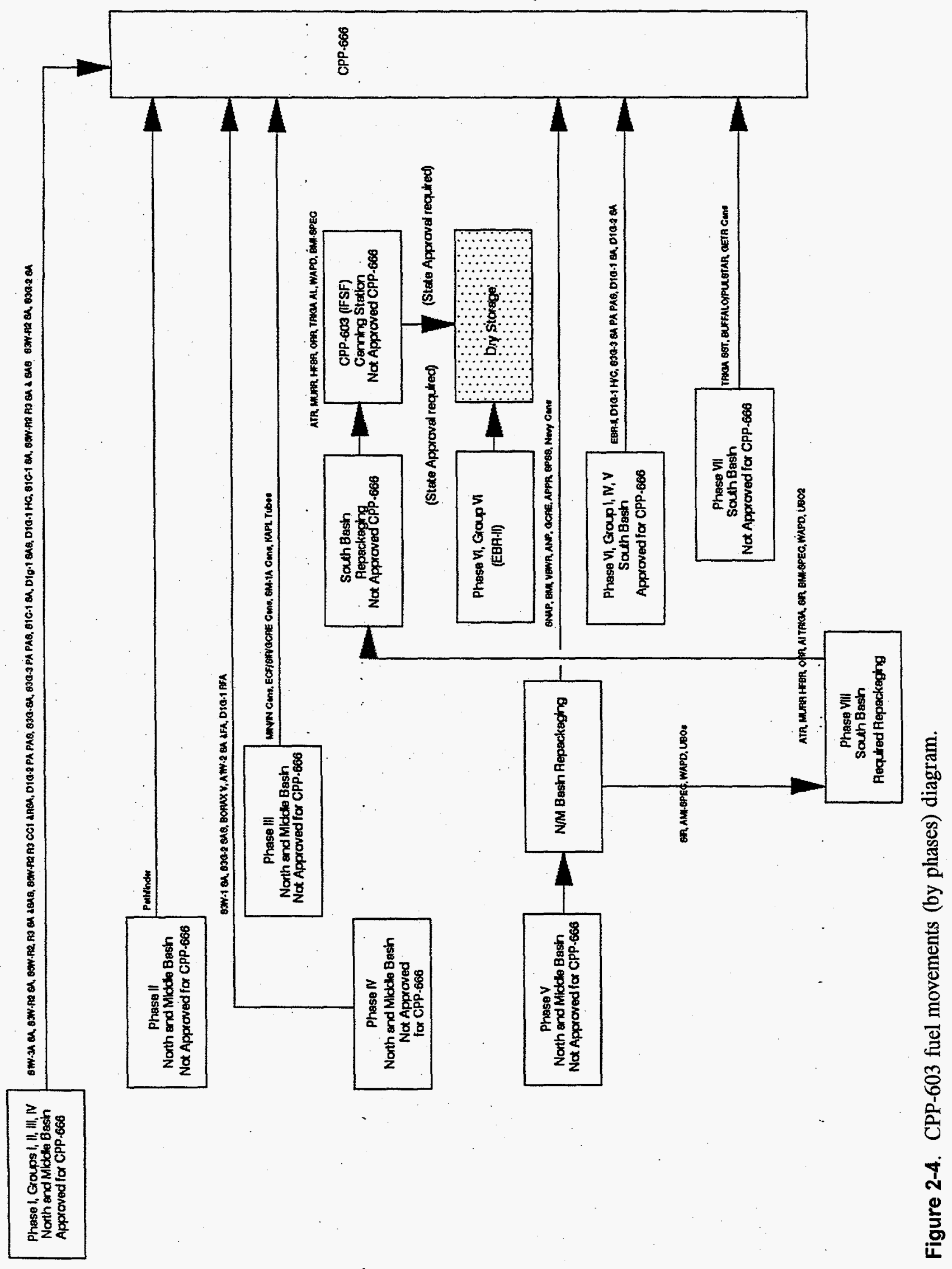


Experimental Breeder Reactor (EBF)-II fuels, where sodium was used as a bonding material between the fuel meat and the 304 stainless steel cladding to ensure optimum heat conductivity, present additional concerns if the cans leak and cladding is breached. If cladding is breached sodium can diffuse out of the stainless steel cladding matrix. Argonne National Laboratory-West (ANL-W) has demonstrated a fast, compact process called electrorefining, that was originally developed to treat small amounts of SNF from the EBR-II. Tests demonstrated a high-capacity version of the electrorefiner that can handle much larger quantities. The presence of the sodium metal may require that the SNF be managed as Resource Conservation and Recovery Act (RCRA) identified material. Thus, treatment of this fuel type in the electrorefining process is being evaluated.

\subsection{Issues and Problems}

Due to the poor condition of the fuel stored in CPP-603, the main issues and problems are associted with the handling, lifting, and packaging of the fuel. As stated under the previous section, technology developement, scoping studies to identify tools and equipment required for fuel repackaging, transportation, and storage in CPP-666 are underway to resolve these issues utilizing existing technologies.

\subsection{Schedules}

The summary level and detailed schedules for the CPP-603 relocation activities are presented in Volume II of this SISMP. The schedules are based on the FY-96 approved baseline costs accounts level schedules submitted under Activity Data Sheets (ADS-1010). Each of these schedules is reviewed by the project manager on a weekly basis and updated monthly. Changes are allowed to the working schedules for those activities that are not directly effecting the approved milestones. Required milestone changes are approved through the Change Control Board (CCB) DOE request system. The baseline level 3 schedules for the current budget year are very detailed. Follow on years are scheduled but are inherently more uncertain as to the level of resources; which might be available and are therefore limited in information. These out year schedules are available, but have not been approved as baseline schedules until the costs accounts are formally approved through the DOE system.

Planning for fuel movements involving the CPP-603 facility is based on the following assumptions:

- Three months is allowed for DOE review and approval of safety documentation.

- The equipment procurement and fabrication will support accelerated schedule.

- Naval fuel receipts which are scheduled through 2027 and are anticipated to continue for storage until at least 2027 will not impact completion of the relocation of SNF from CPP-603 to CPP-666.

- The CPP-666 facility will be operated and maintained throughout its stated lifetime to prevent loss of storage capacity, water quality, or regulatory status. 
- The Phase 1 reracking effort will be completed as scheduled.

- The postulated structural problems at the CPP-603 IFSF will be resolved such that the facility will retain its usability status for SNF storage.

\subsection{Costs}

The costs for completion of the CPP-603 fuel transfers as outlined in the DNFSB Recommendation 94-1 Implementation Plan are being revised based on the schedules shown in Volume II and will be provided later. 
INEL-95/0477

\section{CPP-603 Underwater Fuel Storage Facility Site Integrated Stabilization Management Plan (SISMP)}

\section{Volume II}

R. D. Denney

Published October 1995

Idaho National Engineering Laboratory Nuclear Operations Department Lockheed Idaho Technologies Company Idaho Falls, Idaho 83415

Prepared for the

U.S. Department of Energy

NMSTG : EM-60

Under [IOE Idaho Operations Office

Contract DE-AC07-94ID13223 


\section{SUMMARY LEVEL SCHEDULE}

(Fuel Moves by Phase) 


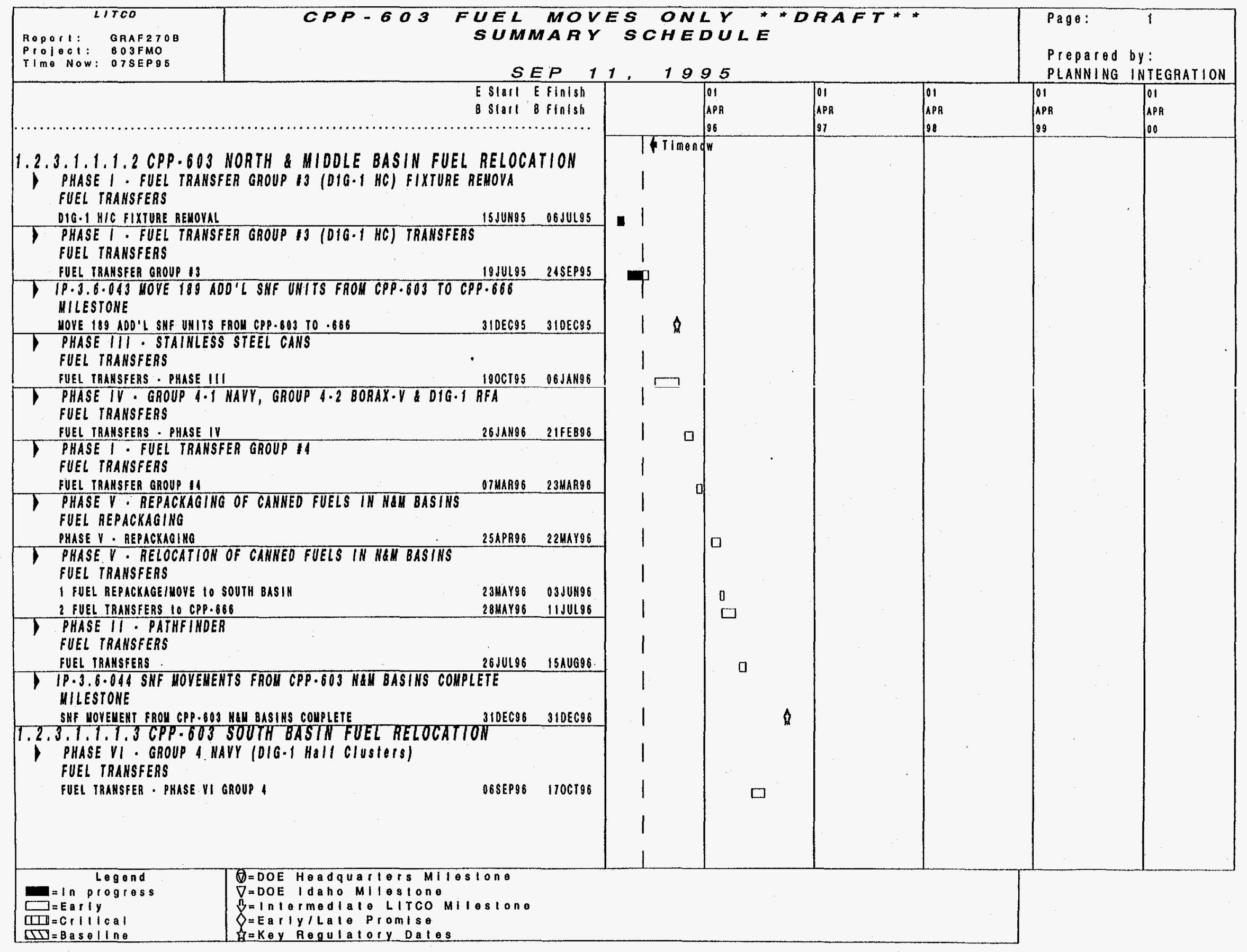




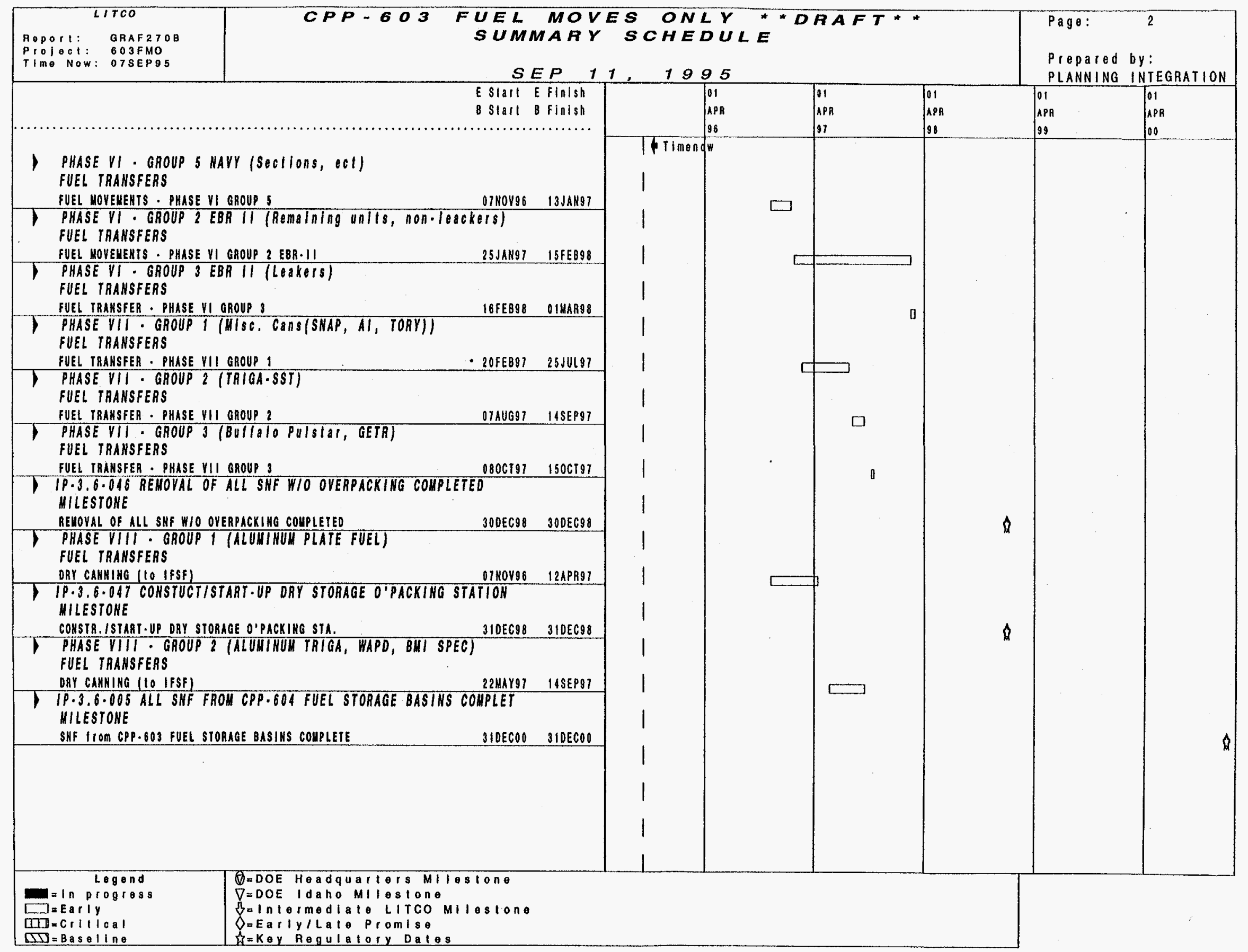




\section{DETAILED LEVEL SCHEDULE}

(Fuel Moves by Phase) 


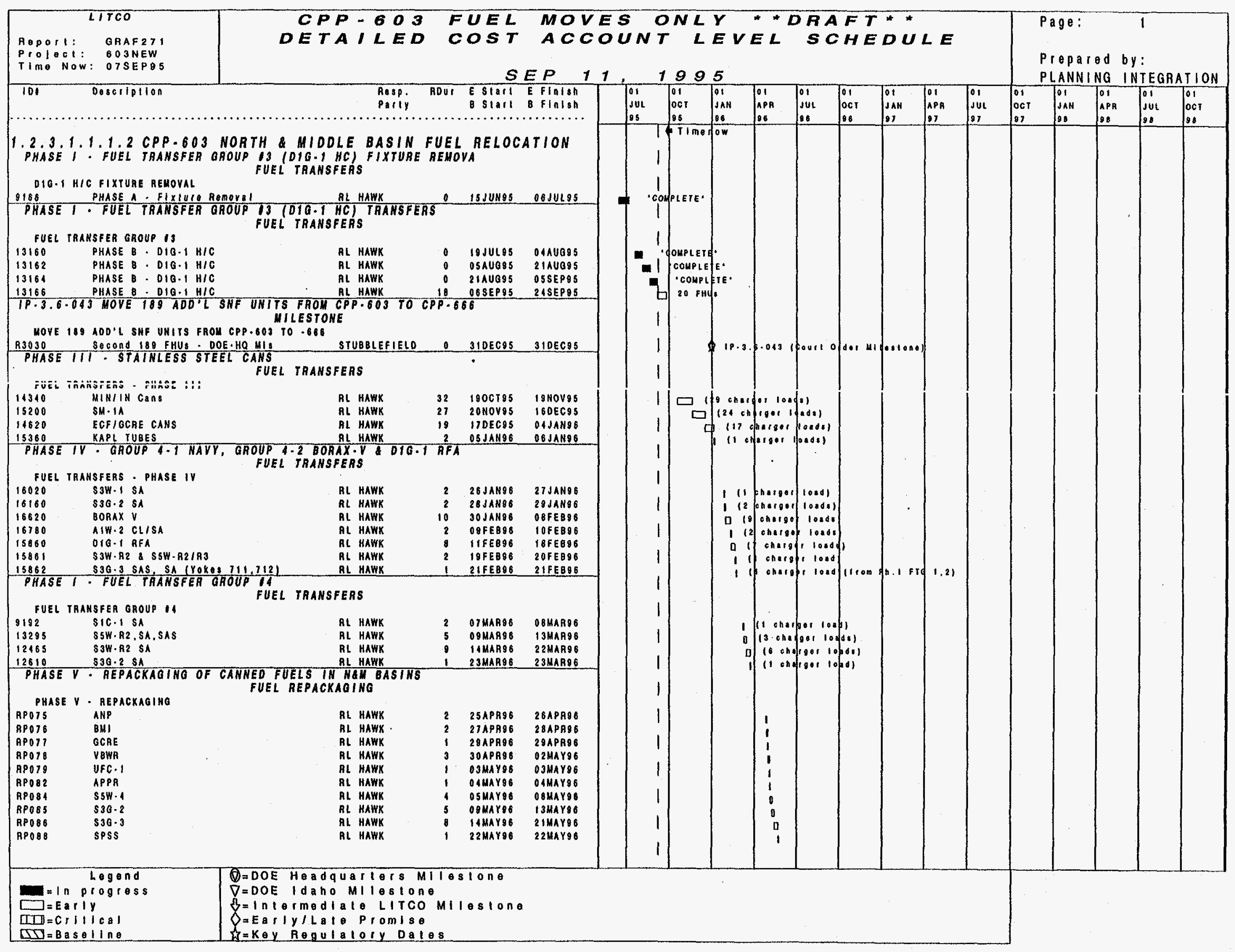




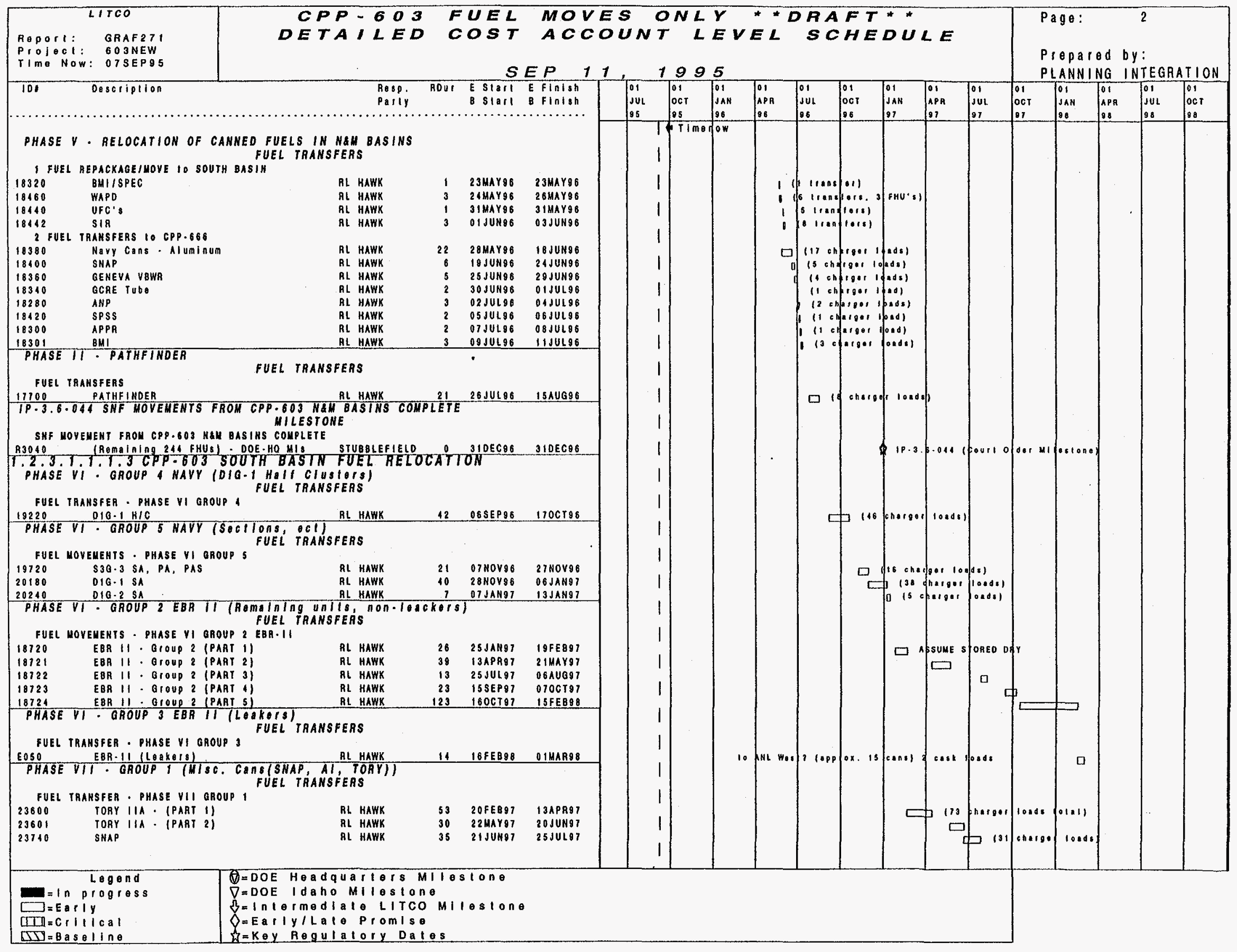




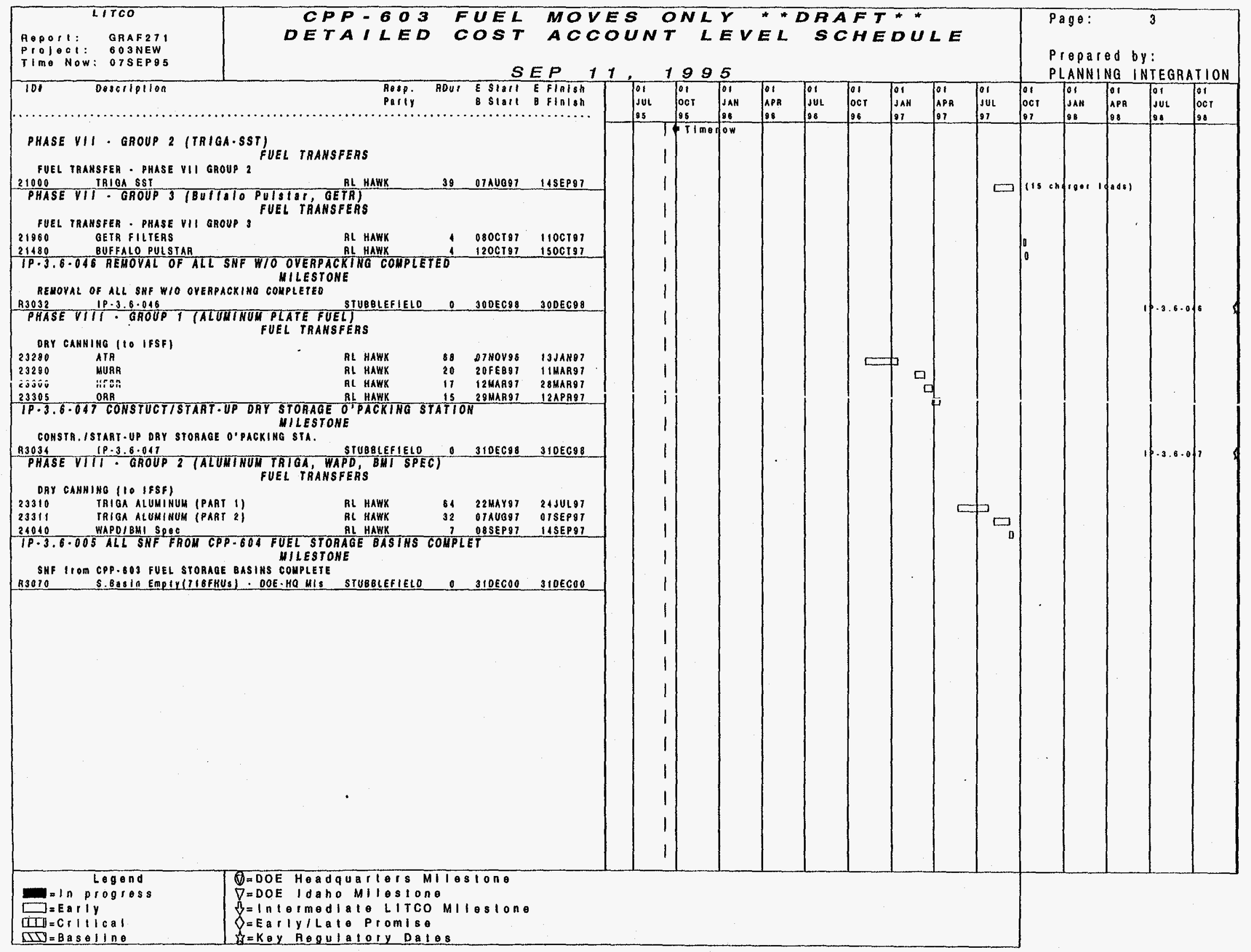


FUEL MOVEMENT PREPARATIONS (Fuel Moves by Phase) 


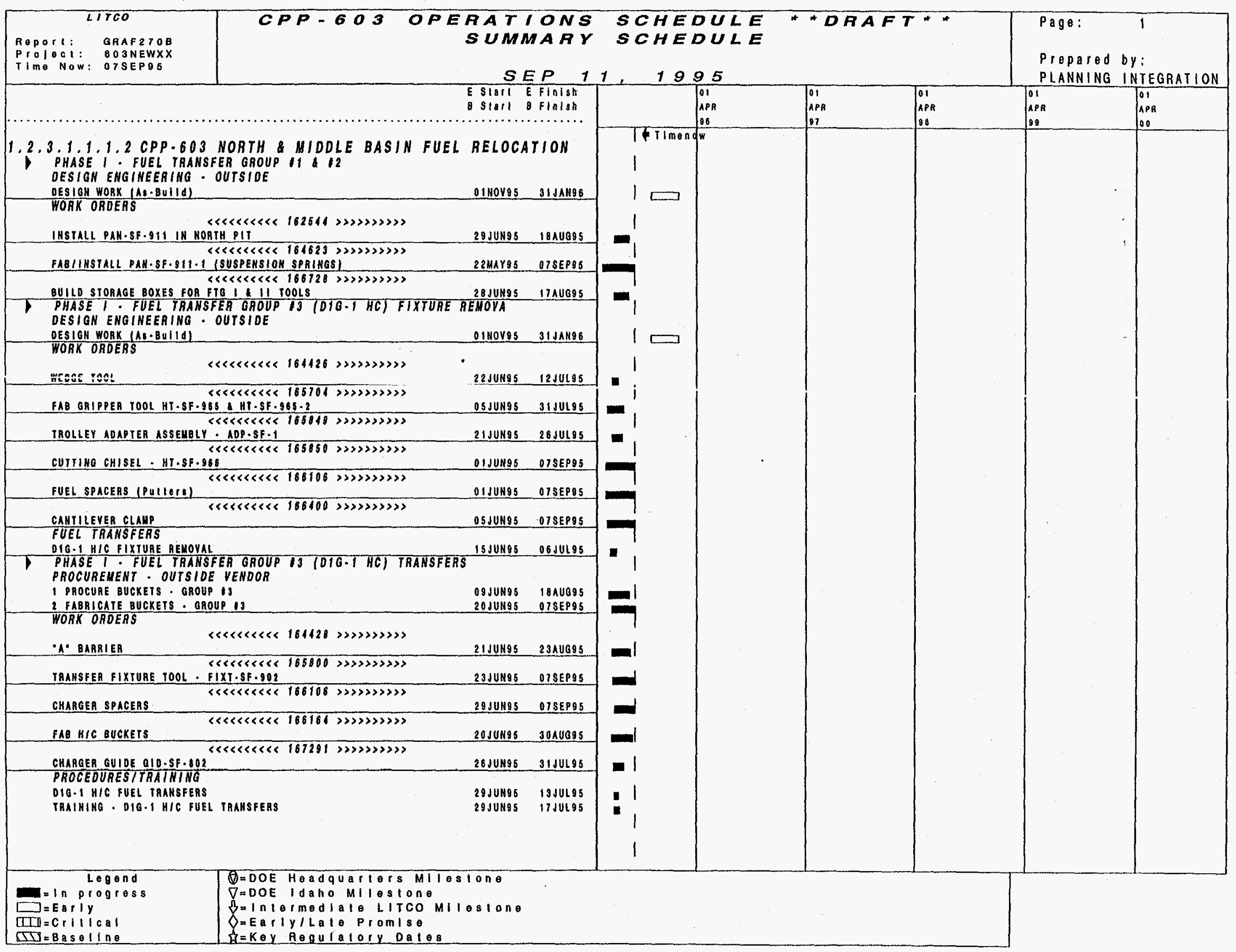




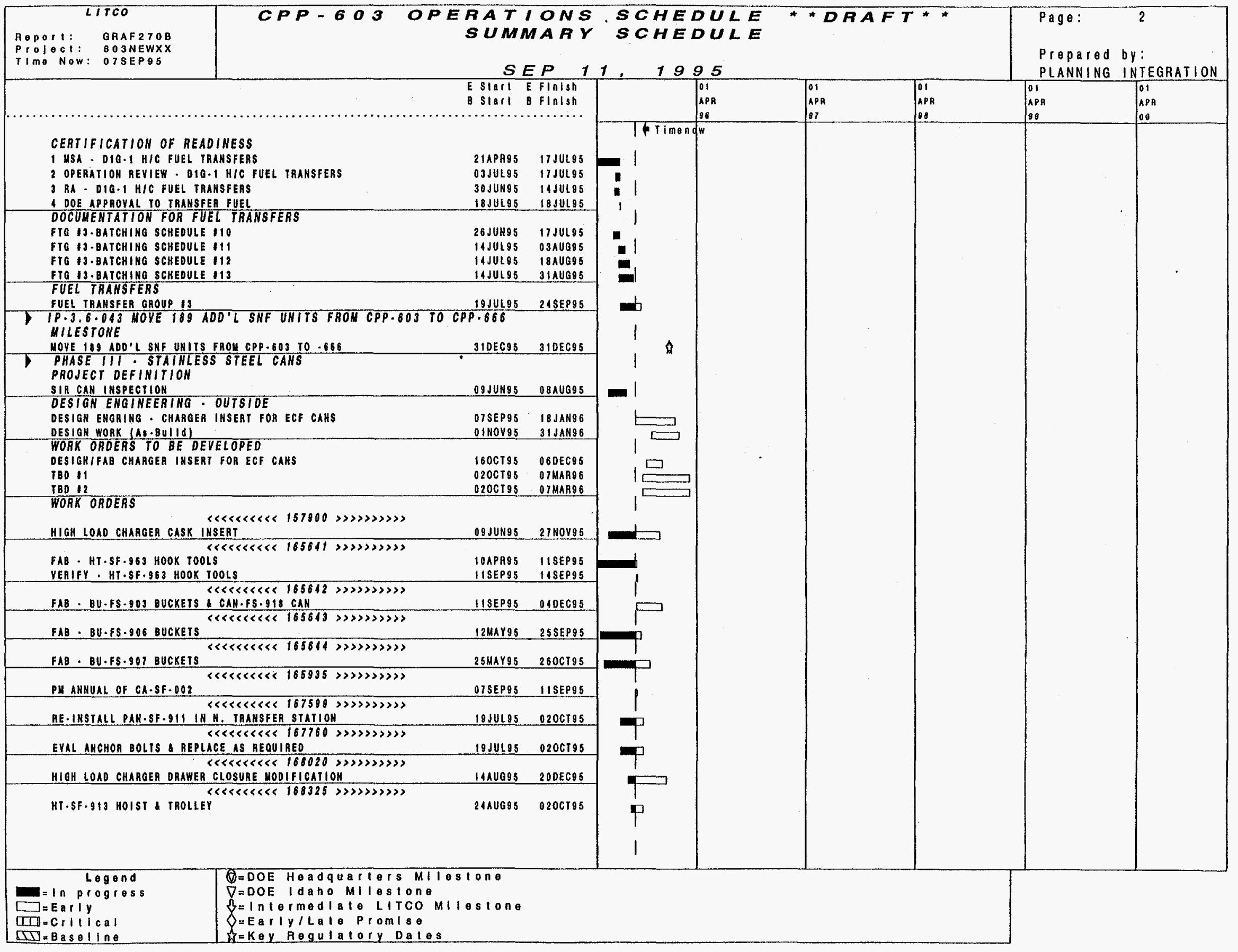




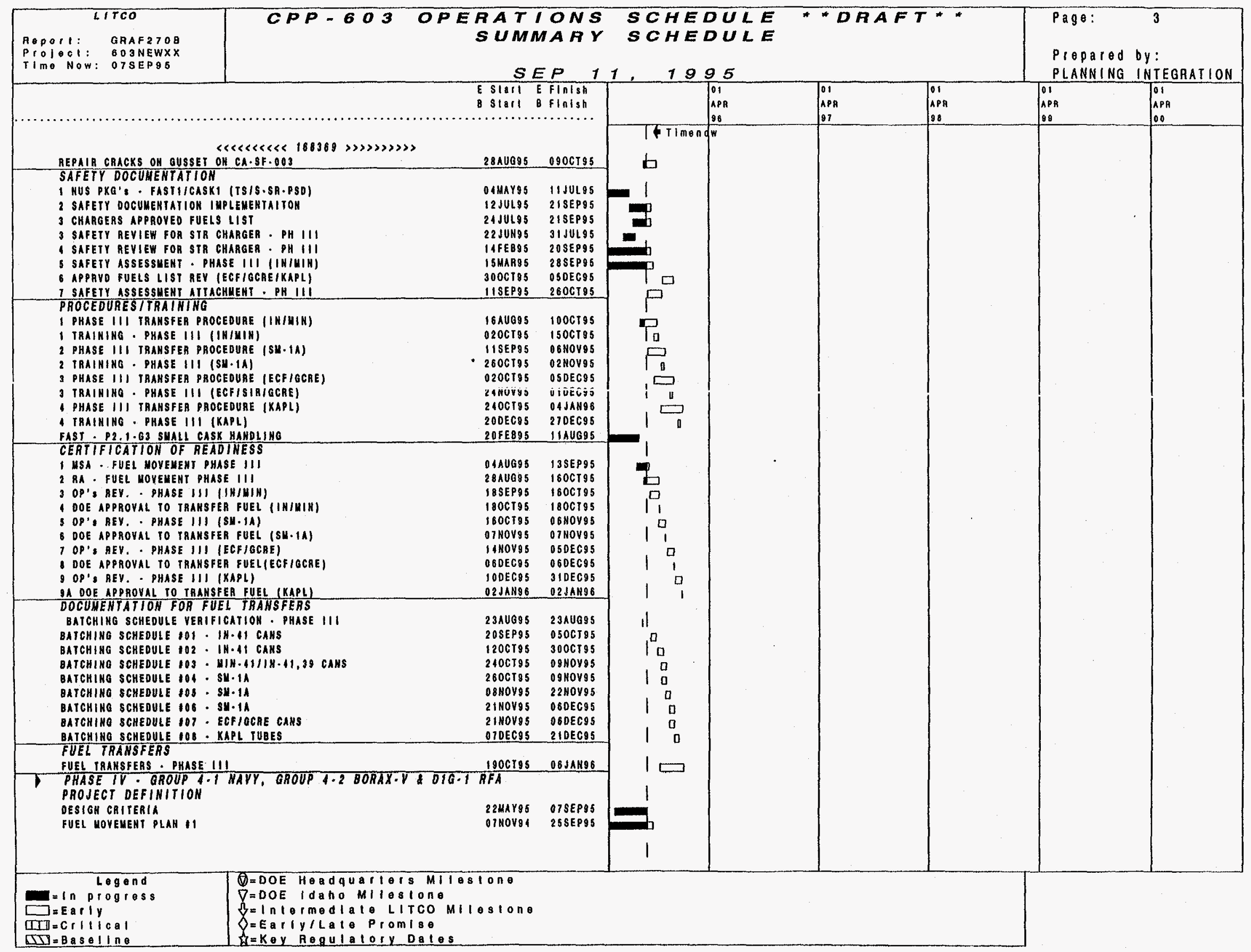




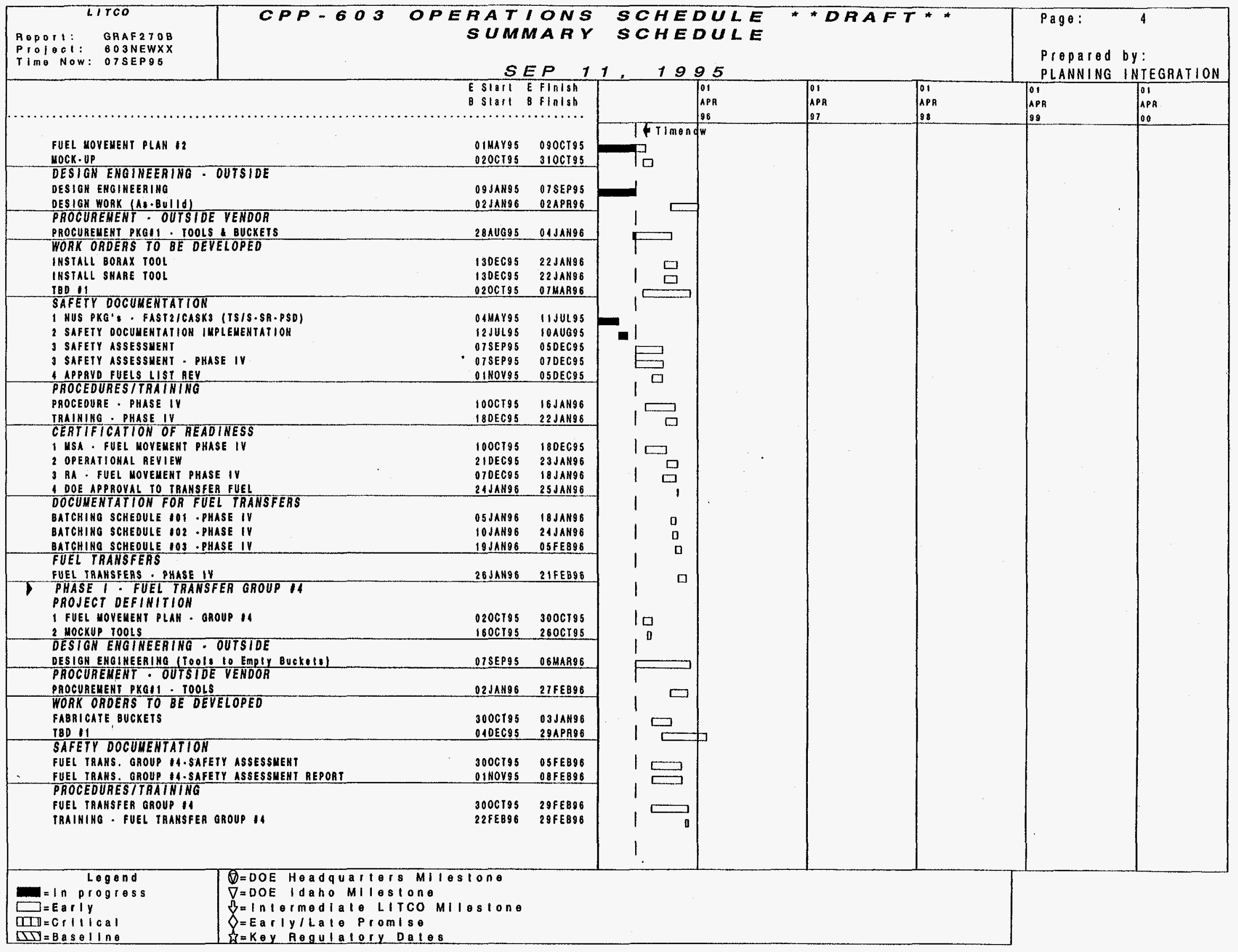




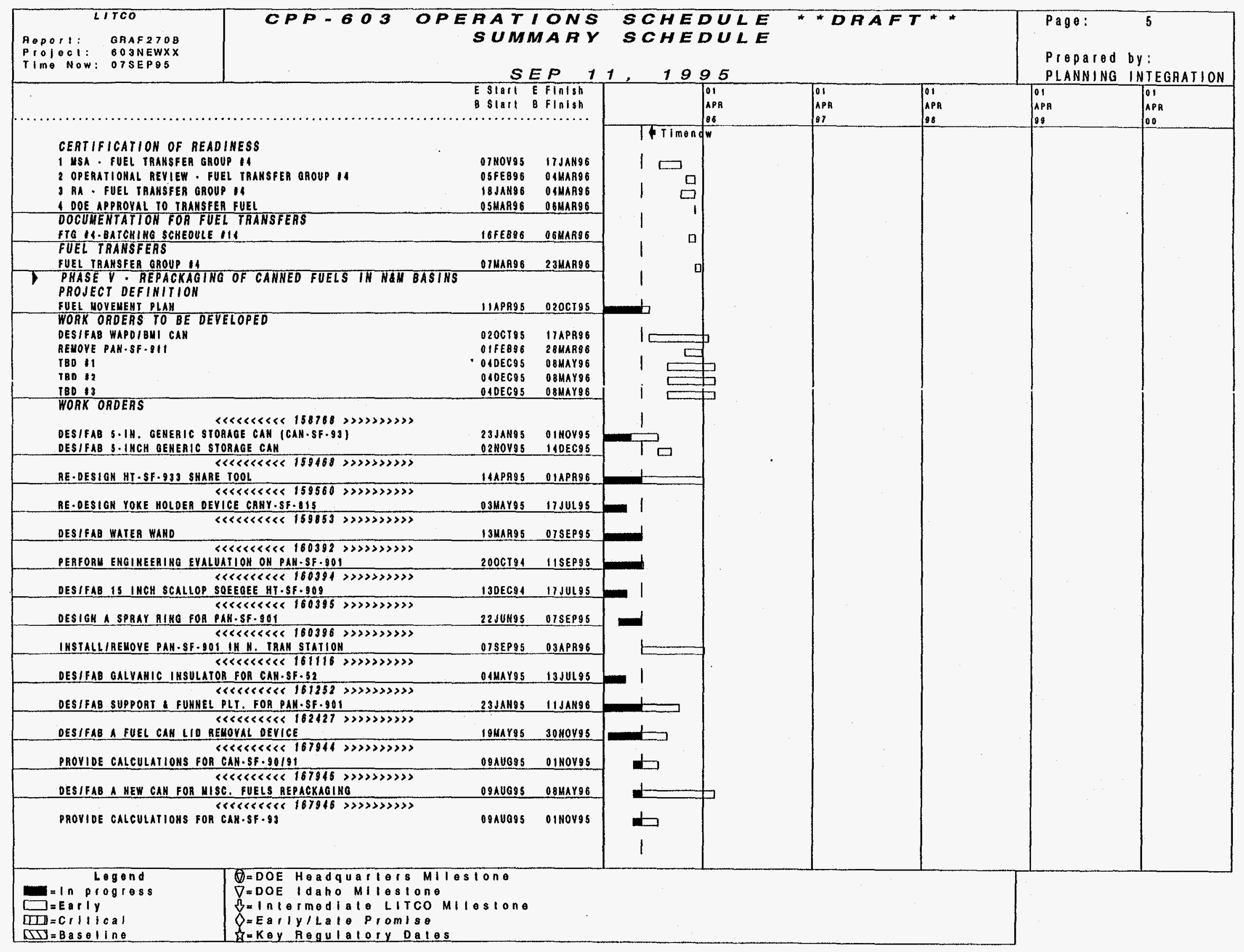




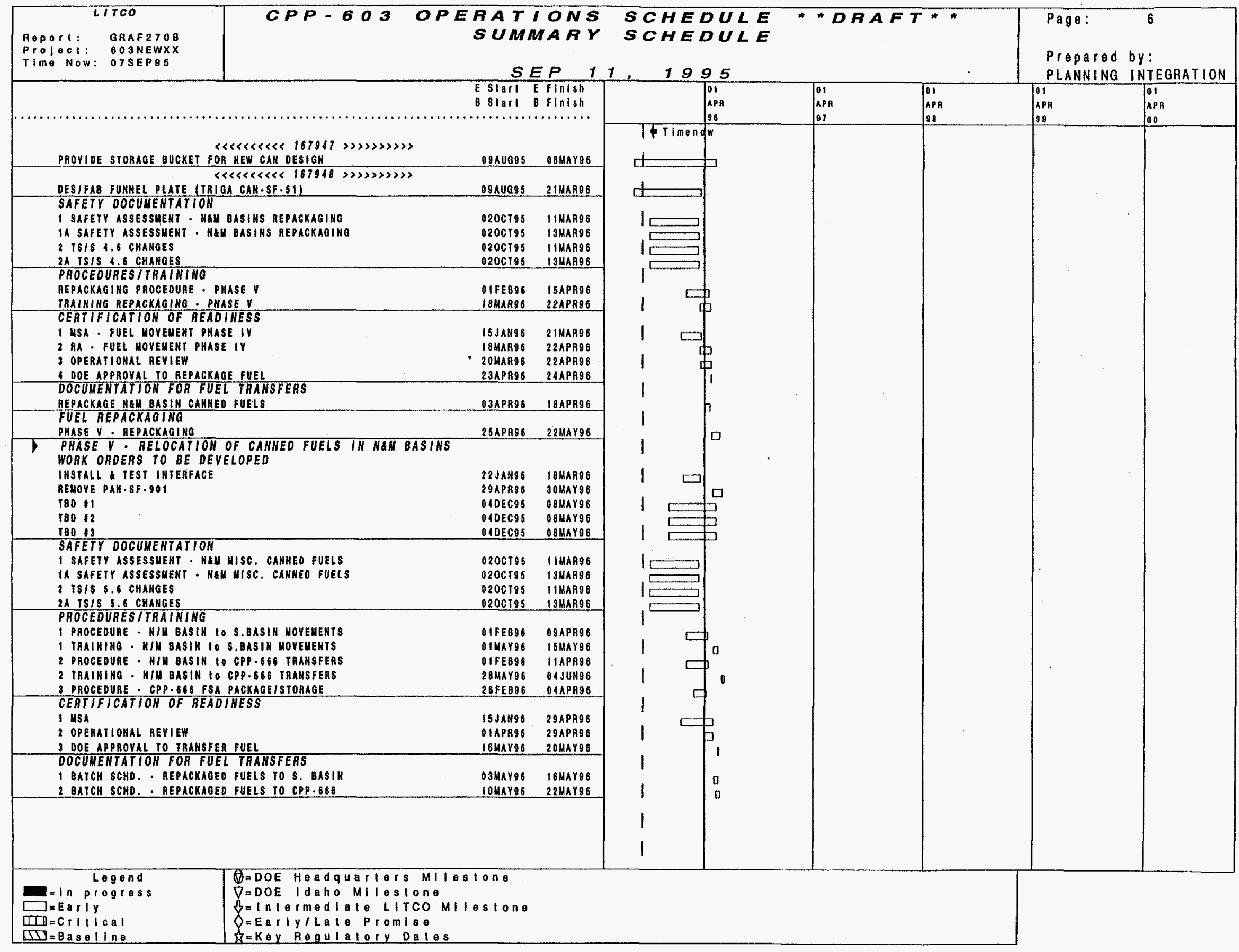




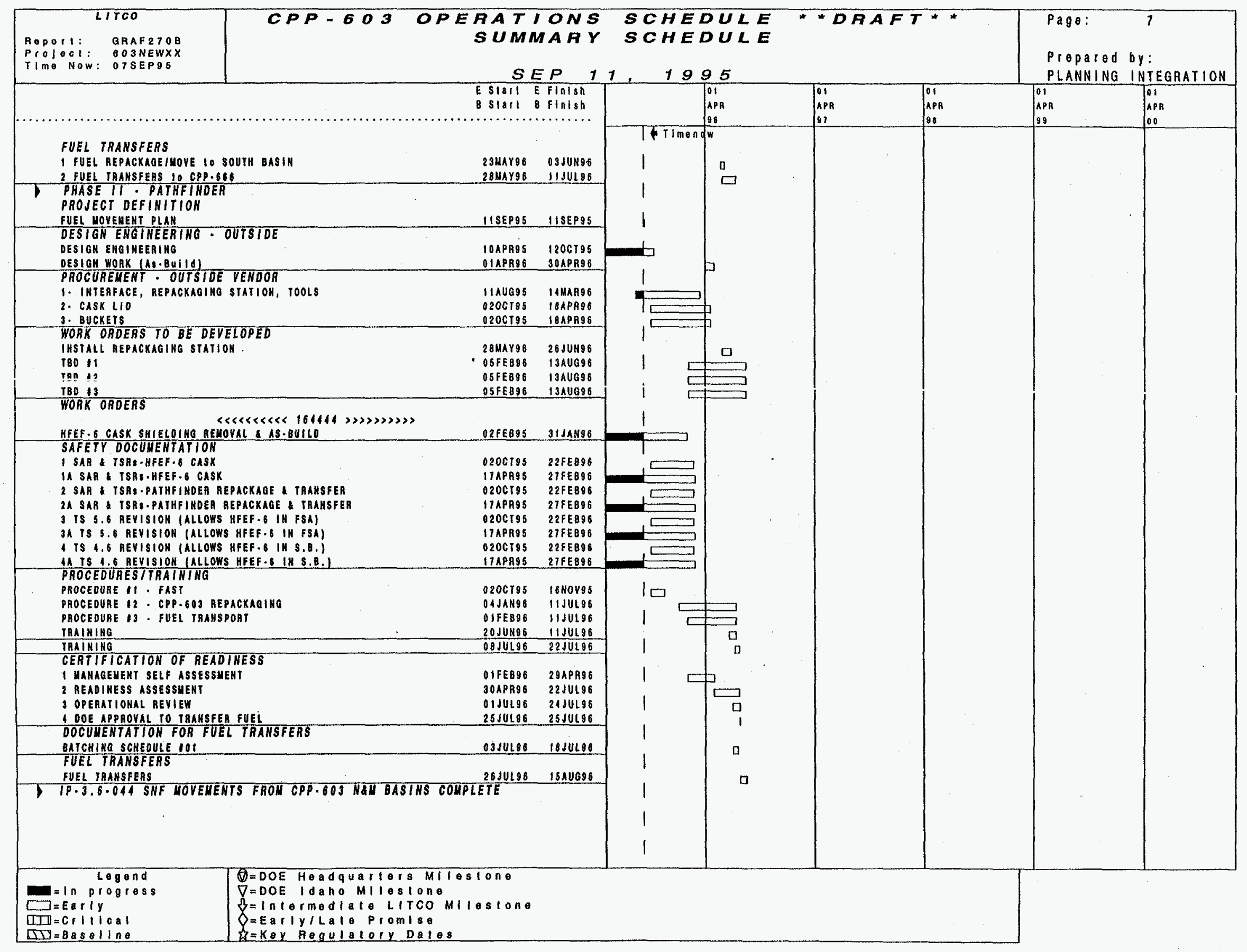




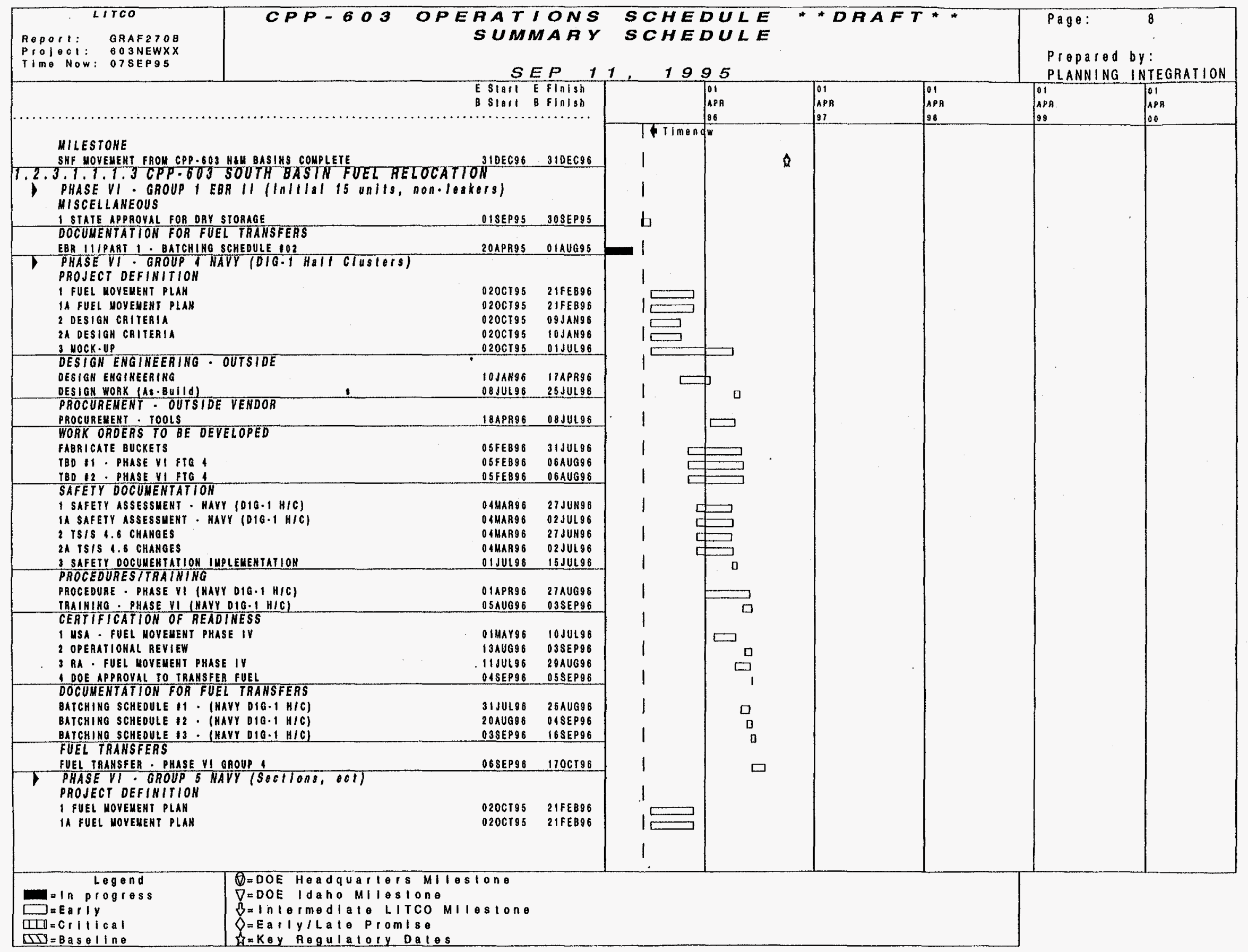




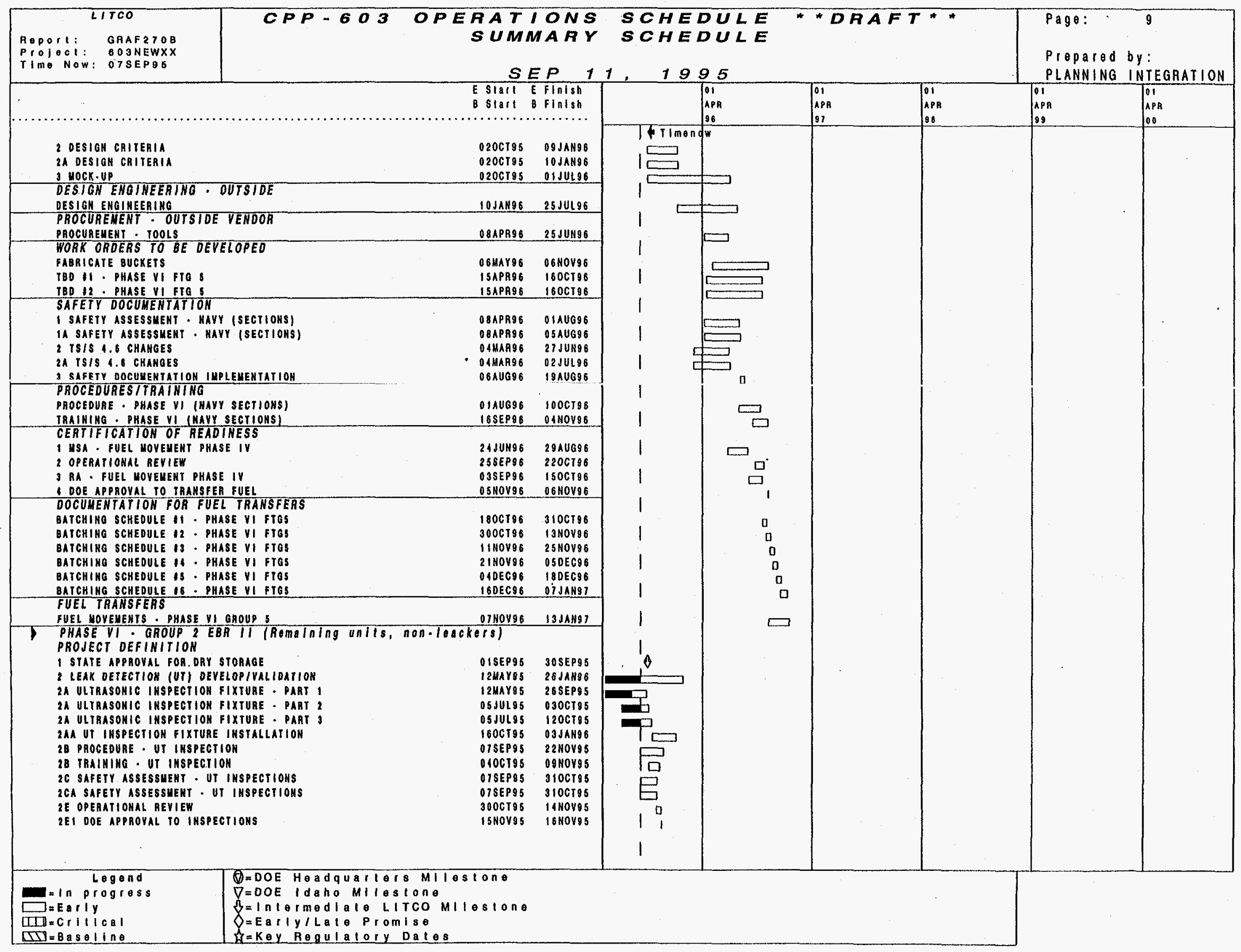




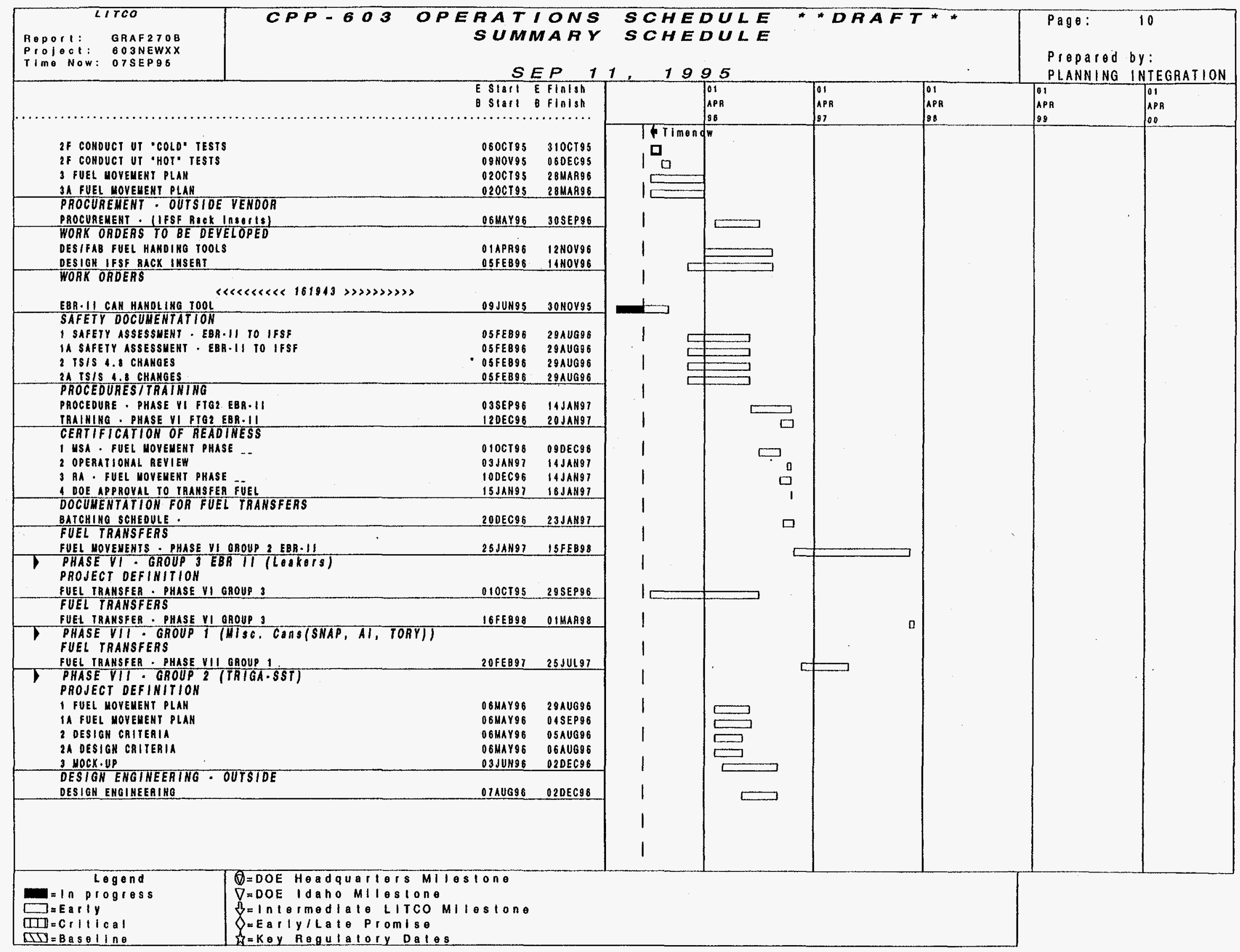




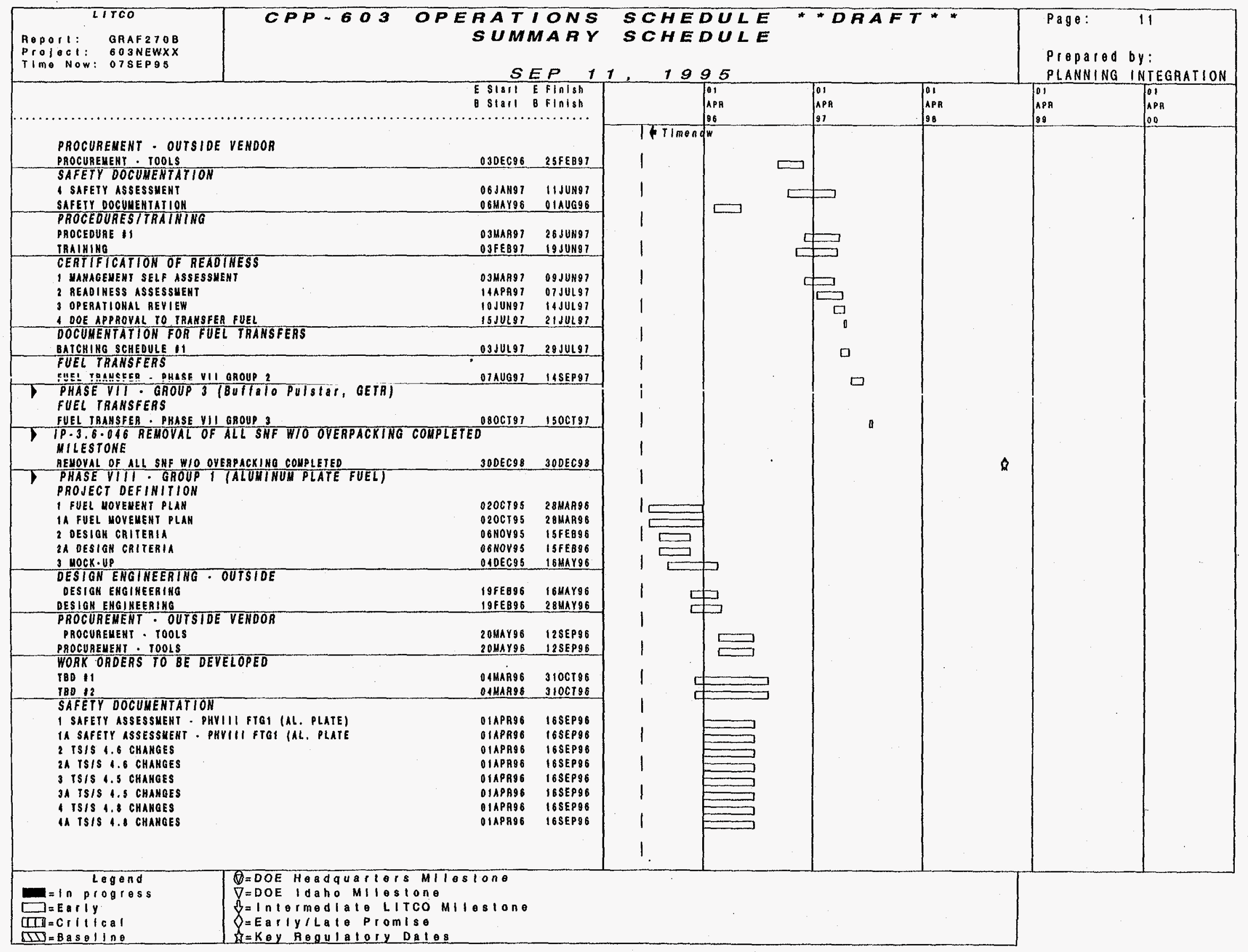




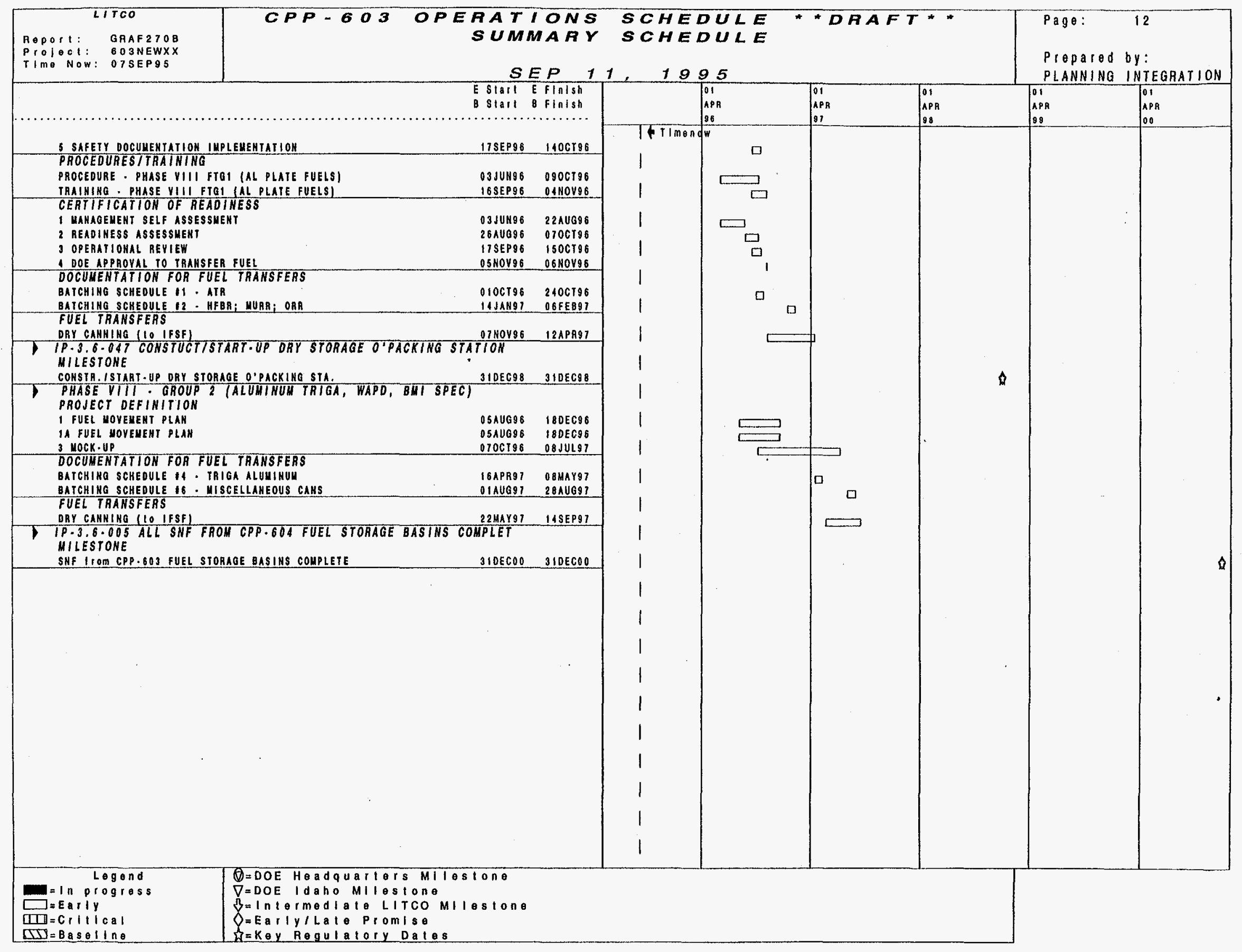


PROGRESS CURVES 


\section{Fuel Transfers From CPP-603 to CPP-666}

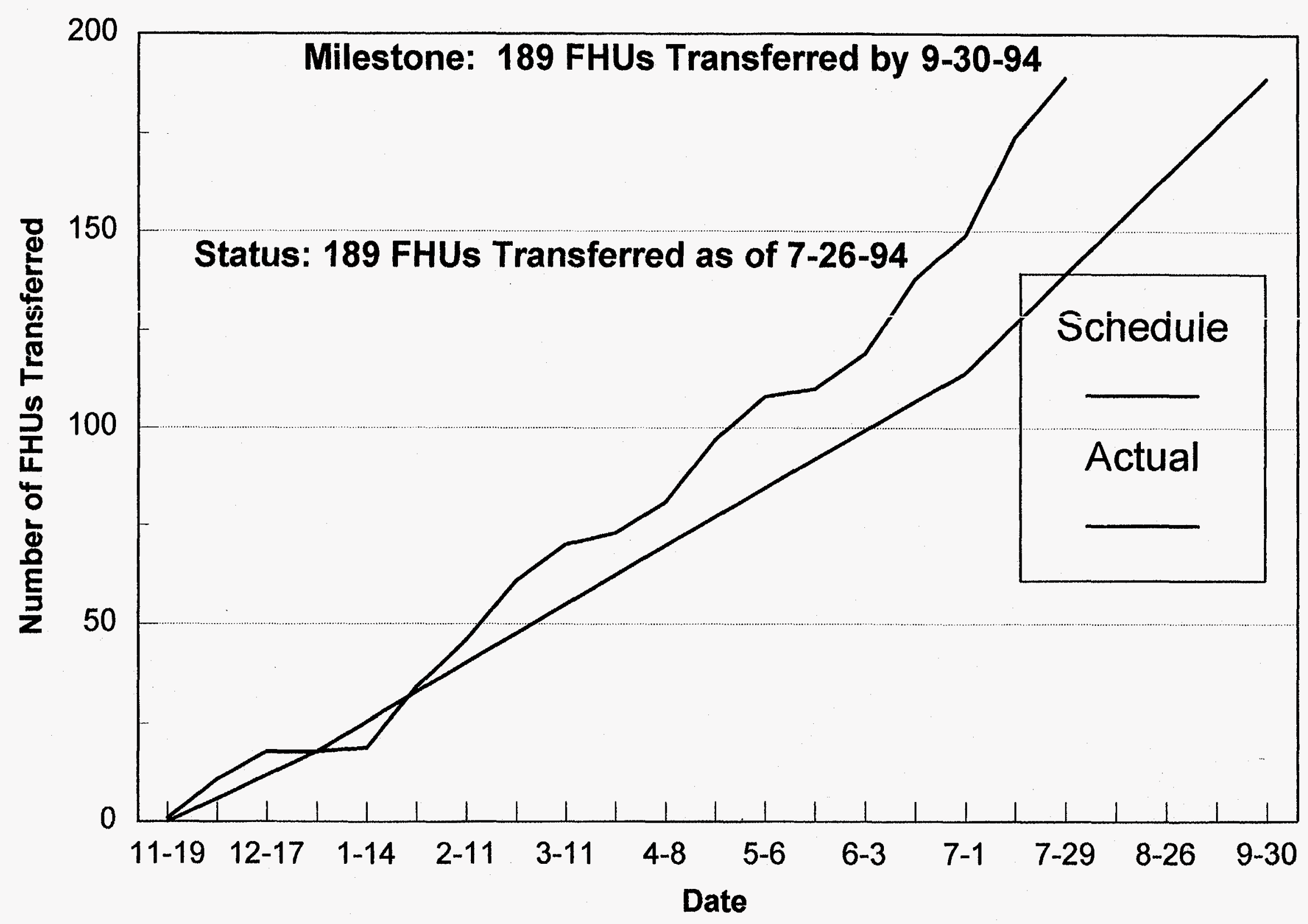




\section{CPP-603 FUEL RELOCATION \\ INTERIM MILESTONES TO MEET COURT ORDER REQUIREMENTS}

Fuel Units

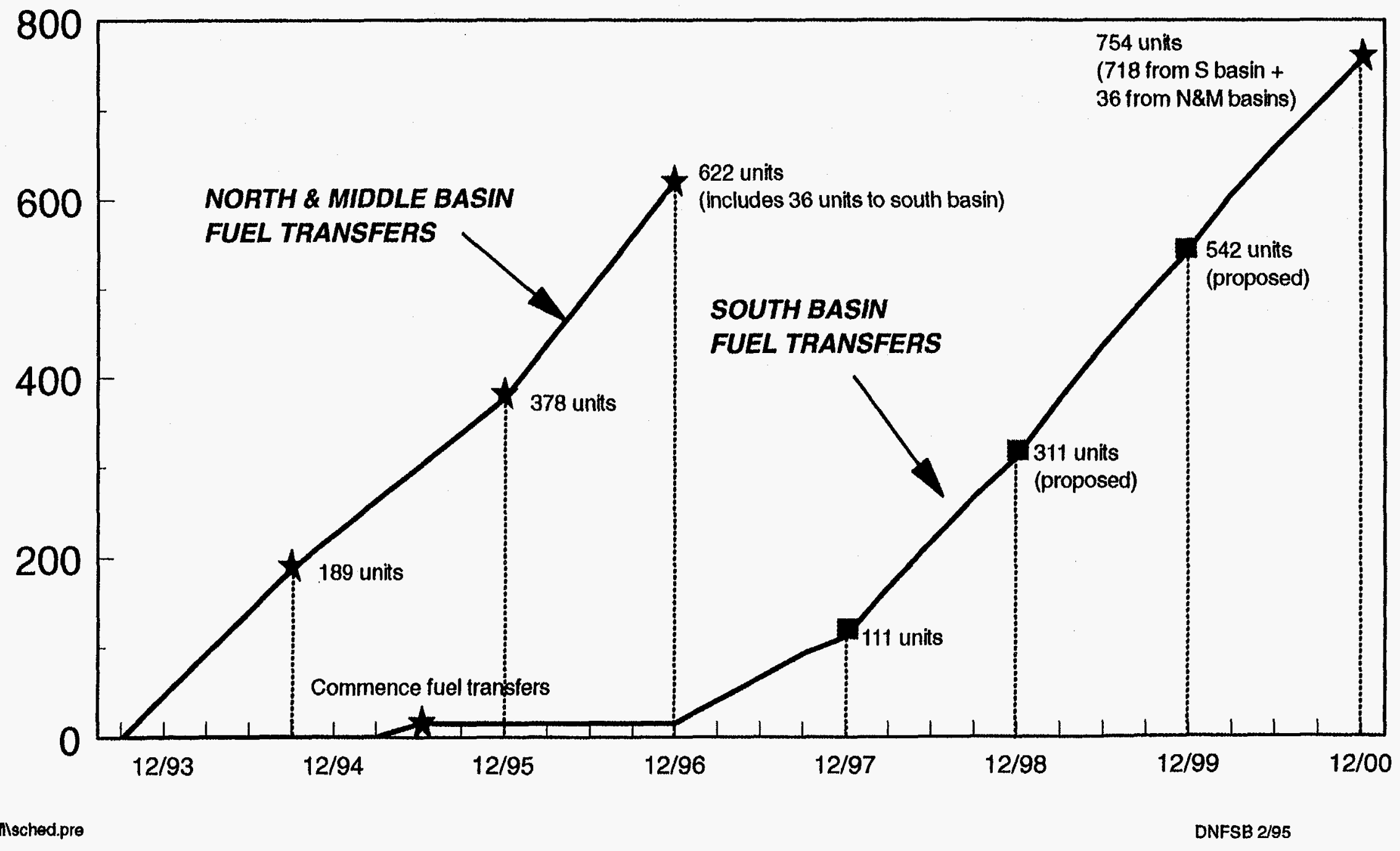




\section{CONTINUED FUEL TRANSFERS FROM CPP-603 to CPP-666}

Revision 1

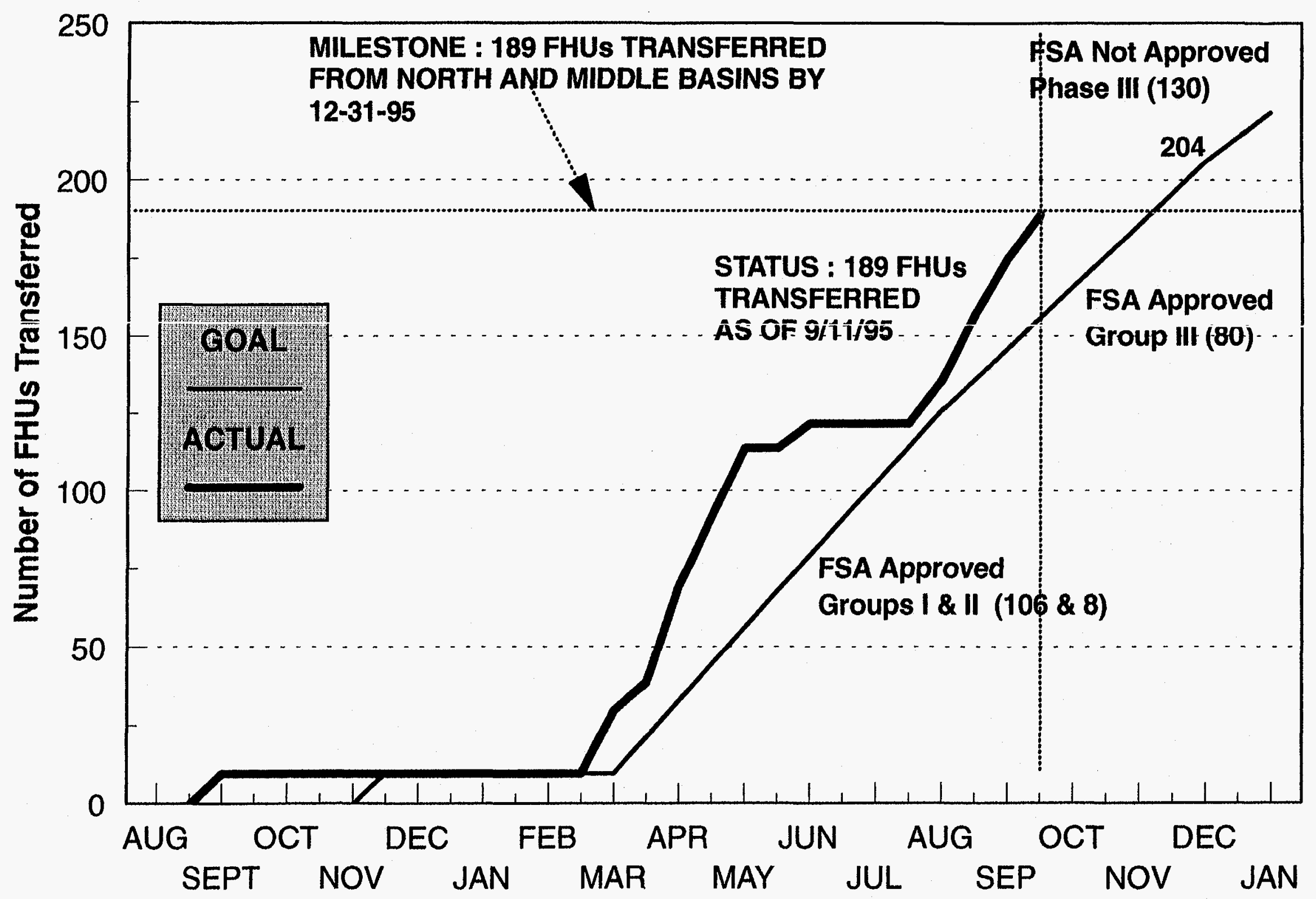




\section{CPP 603 South Basin Fuel Relocation}

Time Scaled Logic Diagram

Rev. 0

$8 / 30 / 1995$

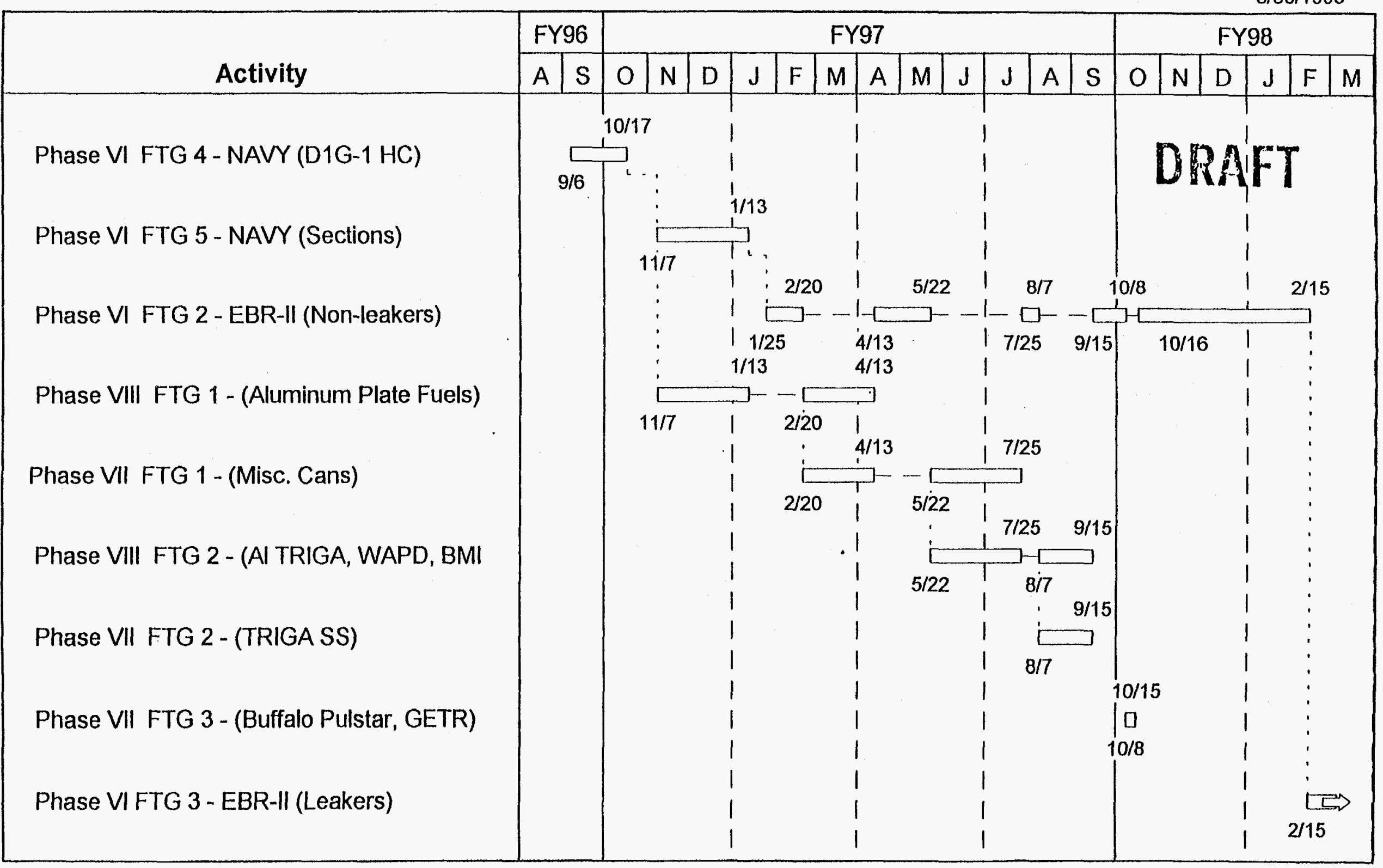




\section{FUEL TRANSFERS FROM CPP-603 SOUTH BASIN}

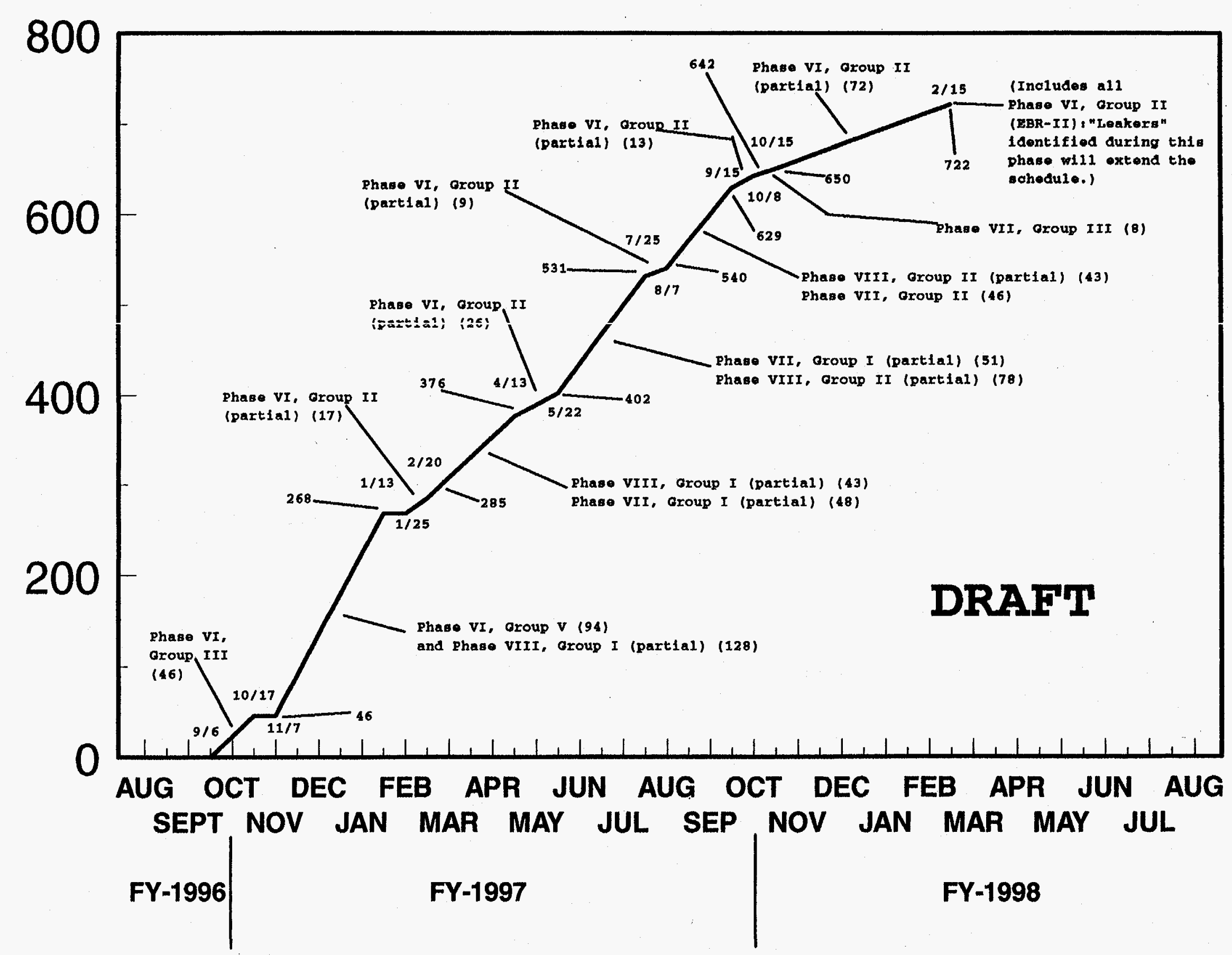




\section{REMAINING FUEL TRANSFERS FROM CPP-603 TO CPP-666}

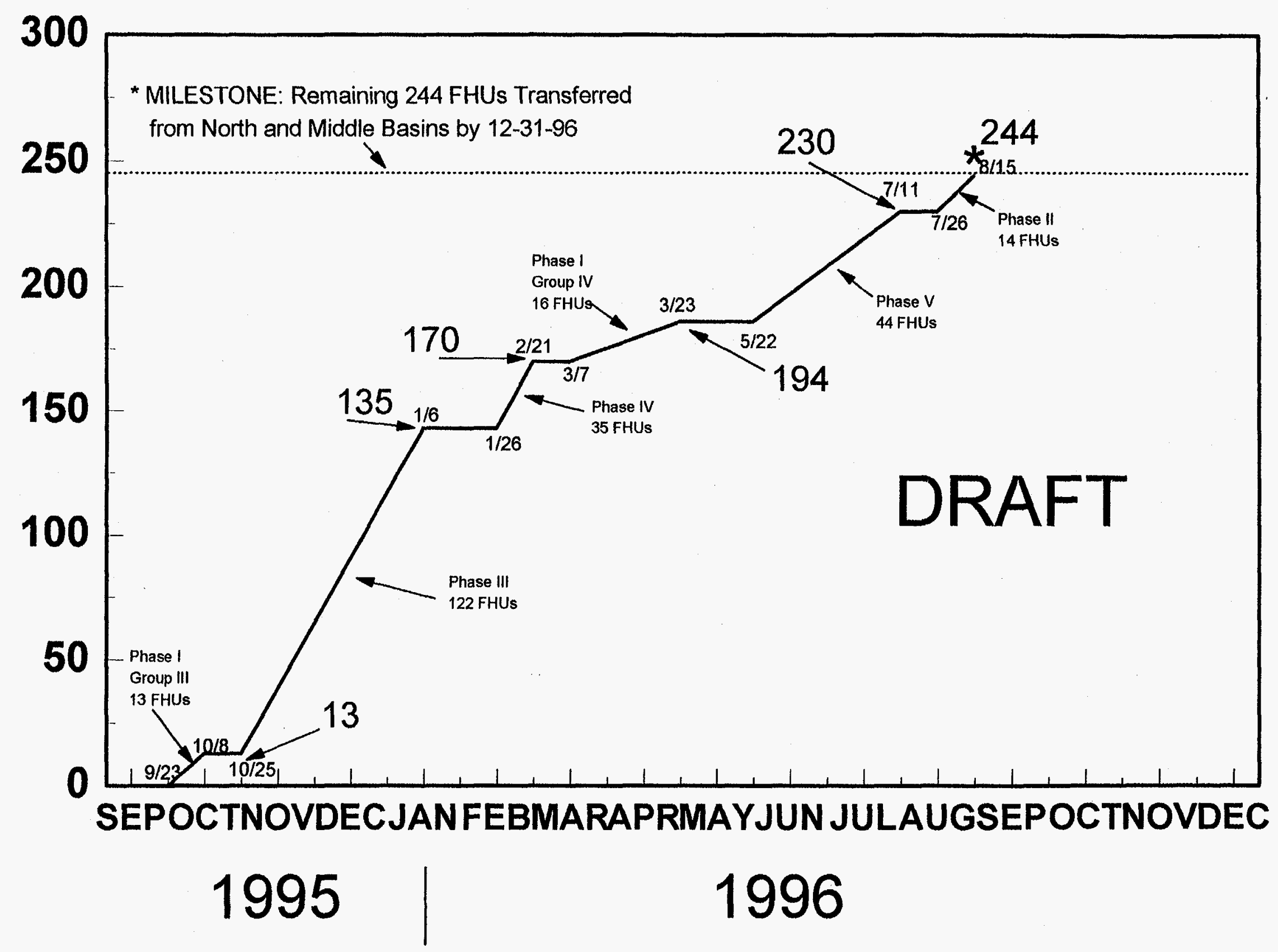




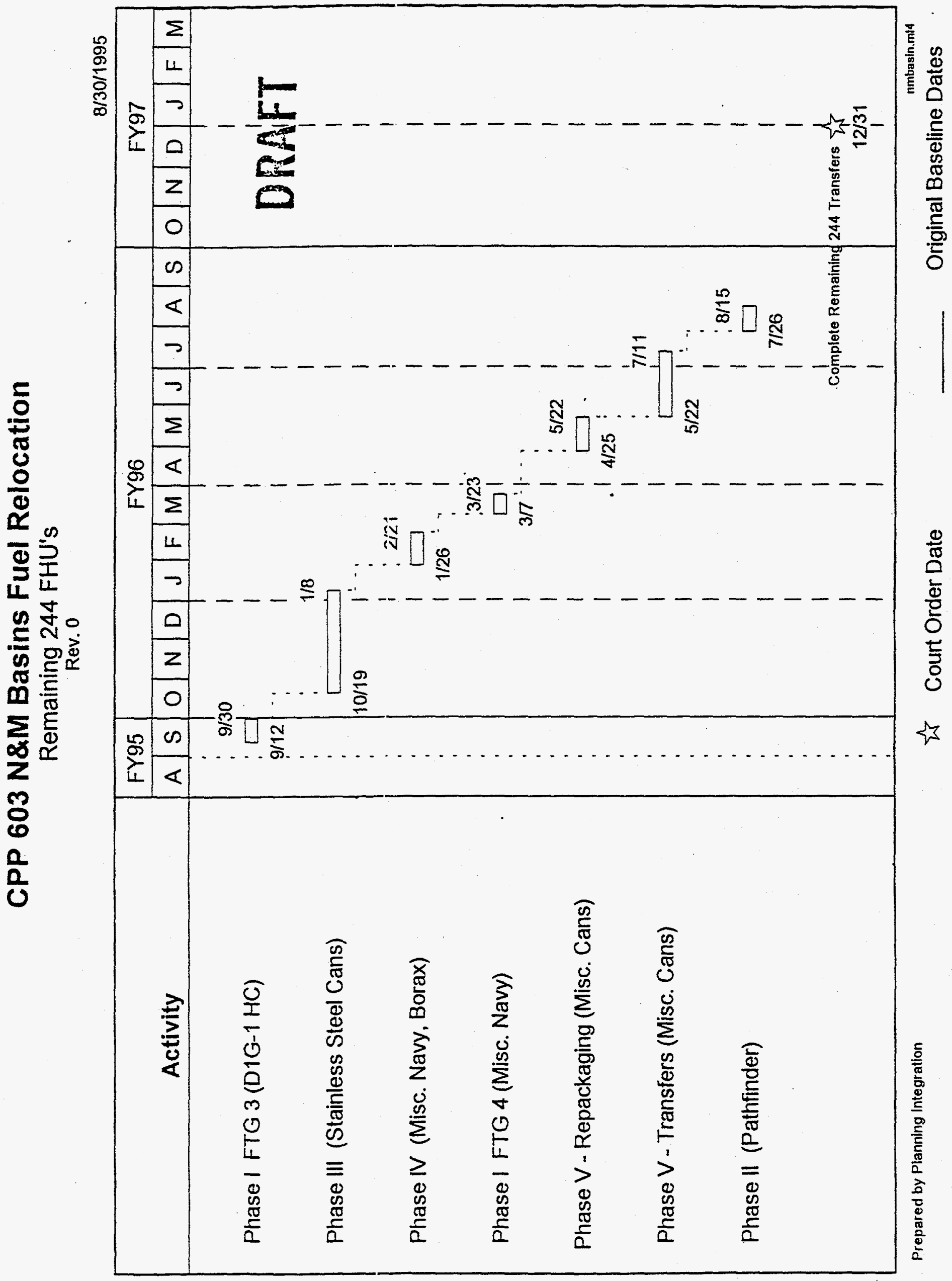

